\title{
Sağlık Çalışanlarında İş Özerkliği ve İş Performansı Arasındaki İlişkide Örgütsel Sinizm ve Yaşam Tatmini Seri Çoklu Arabuluculuğu (Serial Multiple Mediation of Organizational Cynicism and Life Satisfaction in the Relationship Between Job Autonomy and Job Performance in Health Employee)
}

\section{Nilüfer SERİNIKLI iD a}

a Trakya Üniversitesi Uzunköprü Uygulamalı Bilimler Yüksekokulu, İşletme Bilgi Yönetimi Bölümü, Uzunköprü, Edirne, Türkiye. nserinikli@hotmail.com

\begin{tabular}{|c|c|}
\hline MAKALE BİLGİSİ & ÖZET \\
\hline $\begin{array}{l}\text { Anahtar Kelimeler: } \\
\text { İs Özerkliŏi }\end{array}$ & $\begin{array}{l}\text { Amaç - İşözerkliğinin iş performansına etkisinde örgütsel sinizmin ve yaşam tatmininin seri-çoklu aracı } \\
\text { etkisini araştırmaktır. }\end{array}$ \\
\hline İş Performansı & Yöntem - Araştırma, Kırklareli ilinde faaliyet gösteren özel hastane çalışanlarına yönelik yapılmıştır. \\
\hline Örgütsel Sinizm & $\begin{array}{l}\text { raştırmaya toplam } 153 \text { kişi katılmıştır. Elde edilen veriler analizi için SPSS } 20.0 \text { ve Amos } 20 \text { paket } \\
\text { rogramları kullanılmıştır. Hipotezlerin testi için, bootstrap yöntemine dayanan IBM SPSS Process Makro }\end{array}$ \\
\hline Yaşam Tatmini & ygulaması ile test edilmiştir. \\
\hline Sağlık Çalışanları & $\begin{array}{l}\text { Bulgular - İş özerkliğinin, iş performansı ve yaşam tatmini üzerinde olumlu ve anlamlı bir etkisinin } \\
\text { olduğu saptanmıştır. İş özerkliğinin örgütsel sinizm üzerinde negatif yönde anlamlı bir etkisinin olduğu } \\
\text { saptanmıştır. Model 1, araştırmada toplam etki değeri } 0,270 \text {, doğrudan etki değeri } 0,233 \text { ve toplam dolaylı }\end{array}$ \\
\hline $\begin{array}{l}\text { Gönderilme Tarihi } 21 \text { Nisan } \\
2020\end{array}$ & $\begin{array}{l}\text { etki değeri } 0,037 \text { olarak bulunmuştur. Ayrıca araştırmada bootstrap güven aralıklarının }(-0,003-0,007) \text { sıfır } \\
\text { içermesi nedeniyle iş özerkliğinin iş performansına etkisinde bilişsel sinizmin ve yaşam tatmini seri-çoklu } \\
\text { aracı rolünün olmadığı tespit edilmiştir. Araştırmanın diğer bir sonucuna göre ise, Model 2, araştırmada }\end{array}$ \\
\hline $\begin{array}{l}\text { Revizyon Tarihi } 3 \text { Haziran } \\
2020\end{array}$ & $\begin{array}{l}\text { toplam etki değeri } 0,270 \text {, doğrudan etki değeri } 0,206 \text { ve toplam dolaylı etki değeri } 0,064 \text { olarak } \\
\text { bulunmuştur. Araştırmada, bootstrap güven aralıklarının }(-0,004-0,012) \text { sifır içermesi nedeniyle iş }\end{array}$ \\
\hline $\begin{array}{l}\text { Kabul Tarihi } 15 \text { Haziran } \\
2020\end{array}$ & $\begin{array}{l}\text { özerkliğinin iş performansına etkisinde duyuşsal sinizmin ve yaşam tatmini seri-çoklu aracı rolünün } \\
\text { olmadığı tespit edilmiştir. }\end{array}$ \\
\hline $\begin{array}{l}\text { Makale Kategorisi: } \\
\text { Araştırma Makalesi }\end{array}$ & $\begin{array}{l}\text { Tartışma - Araştırmada iş özerkliği, iş performansı, örgütsel sinizim ve yaşam tatmini değişkenleri } \\
\text { arasındaki ilişkiler olduğu saptanmıştı. Literatürde daha önce yapılan çalışmalar, bu sonucu } \\
\text { desteklemektedir. İş özerkliğinin iş performansına etkisinde örgütsel sinizm ve yaşam tatmininin seri- } \\
\text { çoklu aracı etkisinin olacağı düşünülmüştür. Ancak, elde edilen sonuçlarda örgütsel sinizm ve yaşam } \\
\text { tatmininin seri-çoklu aracı etkisinin olmadığ testpit edilmiştir. }\end{array}$ \\
\hline ARTICLE INFO & ABSTRACT \\
\hline Keywords: & $\begin{array}{l}\text { Purpose - The serial-multiple mediation of organizational cynicism and life satifaction in the impact of } \\
\text { job autonomy on job performance. }\end{array}$ \\
\hline $\begin{array}{l}\text { Job Performance } \\
\text { Organizational Cynicism }\end{array}$ & $\begin{array}{l}\text { Design/methodology/approach - Research has been done towards employees of private hospital being } \\
\text { active in Kurklareli province. Total } 153 \text { persons have participated in the research. SPSS } 20.0 \text { and Amos } 20 \\
\text { package programs were used for data analysis. For testing hypotheses, it was tested with the IBM SPSS }\end{array}$ \\
\hline Life Satisfaction & Process Macro application based on the bootstrap method. \\
\hline Health Employee & $\begin{array}{l}\text { Findings - It is determined that job autonomy has a positive and meaningful effect on job performance } \\
\text { and life satifaction. İt is determined that job autonomy has a negative and meaningful effect on } \\
\text { organizational cynicism. Model } 1 \text {, in the research, It have been found as total effect value } 0,270 \text {, direct } \\
\text { effect value } 0,233 \text { and total indirect effect value } 0,037 \text {. Besides, in the research, due to including zero value }\end{array}$ \\
\hline Received 21 April 2020 & of bootstrap confidence intervals $(-0,003-0,007)$, it is determined that job autonomy isn't the serial-multiple \\
\hline Revised 3 June 2020 & mediation role of congnitive cynicism and life satisfaction in the impact of job performance. According to \\
\hline Accepted 15 June 2020 & $\begin{array}{l}\text { other result of research, Model } 2 \text {, It have been found as total effect value } 0,270 \text {, direct effect value } 0,206 \\
\text { and total indirect effect value } 0,064 \text {. In the research, due to including zero value of bootstrap confidence } \\
\text { intervals }(-0,004-0,012) \text {, it is determined that job autonomy isn't the serial-multiple mediation role of } c \\
\text { affective cynicism and life satisfaction in the impact of job performance. }\end{array}$ \\
\hline $\begin{array}{l}\text { Article Classiticatio } \\
\text { Research Article }\end{array}$ & $\begin{array}{l}\text { Discussion - In the research, it is determined to be relationships between job autonomy, job performance, } \\
\text { organizational cynicism and life satisfaction variables. Previous studies in the literature is support this } \\
\text { result. It is thought that job autonomy will have the serial-multiple mediation role of organizational } \\
\text { cynicism and life satisfaction in the impact of job performance. However, in the results obtained, it has } \\
\text { been tested that organizational cynicism and life satisfaction has no serial-multiple mediating effect. }\end{array}$ \\
\hline
\end{tabular}




\section{GİRiş}

Sağlık kurumları, açık sistemler olup, en önemli girdi ve çıktısı "insan" dır. Sağlık kuruluşları, insan emeğinin yoğun olarak gerçekleştĭgi örgütlerdir. Hizmetin sunulmasında ve hizmet memnuniyetinin sağlanmasında insan unsuru oldukça önem arz etmektedir. Sağlık kurumlarında, verilen hizmet özellikleri bakımından, diğer hizmet sektörlerine göre farklılık göstermektedir (Köroğlu ve Yardan, 2016: 14). Çünkü sağllk kurumlarında sunulan hizmetler, doğrudan doğruya insan hayatıyla ilgili olup, asla hata kabul etmeyen, acil karar verilmesi gereken ve stoklanamayan özelliğe sahiptir. Bu nedenle, sağlık kurumlarında, yüksek kalitede hizmet verilmesi önem arz etmektedir (Kılınç ve Paksoy, 2017: 153; Şantaş vd., 2016: 869). Örneğin, poliklinik hizmeti almaya gelen bir hastanın, hastaneye girişinden çıkışına kadar bir çok sağlık çalışanı (özel güvenlik, danışma, hemşire, doktor, laboratuar, sekreter, muhasebeci gibi) ile muhatap olmak durumundadır. Her ne kadar tıbbi tedavinin başlangıcından bitişine kadar geçen süreçte doktorun suduğu hizmet mükemmel olsa da, hemşirenin, sekreterin veya veznede çalışan sağlık personelinin negatif tutumlar sergilemesi veya gülümsememesi, hastaların hastaneden mutsuz/memnuniyetsiz olarak ayrılmasına neden olabilir (Tunç, 2018: 15). Hasta bakım kalitesinin, hasta memnuniyetinin ve kurumsal performansın artışı hastane çalışanlarının yüksek kalitede hizmet vermesine bağlıdır. Bu da ancak, yüksek performans gösteren çalışanlar ile mümkün olabilmektedir. Çalışanların yaptıkları işte, yüksek performans göstermesi kurumsal performansın, gelirin ve hasta memnuniyetinin artmasına neden olacaktır (Tekingündüz vd., 2015: 40; Genç, 2018: 170). Çalışanların iş performansını artıran önemli faktörlerden bir tanesi iş özerkliğidir. Özellikle hayati öneme sahip, işlerin ve ast-üst ilişkisinin yoğun olduğu sağlık kurumlarında, sağlık çalışanlarının işlerinde özerk olmaları onların daha yüksek performans göstermesine, etkililik ve verimliliklerinin arttırmasına neden olacaktır. Ancak, işlerinde özerk olmayan çalışanlar, iş ve yaşam tatminlerinde, performanslarında düşüş yaşayacaklar ve sinik tutumlar sergileyeceklerdir (Çiçek, 2018: 2; Tunç, 2018: 25). Örgütsel sinizm yaşayan çalışanlar, genellikle işyerine karşı güvensizlik, alaycı bir şekilde hem işletmeyi hem de çalışma arkadaşlarını eleştirme eğilimi, çalışma arkadaşları ve örgüt ile olan olumsuz ilişkiler, hastalara karşı güvensiz davranışlar gibi bir takım olumsuz tutumlar içerisine girebileceklerdir. İşyerinde yaşanan bu olumsuz durumlar sağlık çalışanlarının memnuniyetsiz olmasına, örgüte karşı yabancılaşmasına, mutsuz olmasına, hayal kırıklığı yaşamasına, işten ayrılma niyeti içerisine girmesine, hatta işten ayrılmasına neden olabilecektir. Bu durum, sağlık çalışanlarının hem iş tatminlerini hem de yaşam tatminlerini olumsuz yönde etkileyecektir (Köroğlu ve Yardan, 2016: 14; Özyer, Irk ve Anaç, 2015: 262). Sinik davranışlar gösteren ve yaşam tatminleri düşük olan sağlık çalışanlarının yüksek performansta çalışmaları söz konusu olmayacaktır. Böylece, sağlık çalışanlarının performansının düşmesine bağlı olarak sağlık kuruluşunun da performansı düşecektir (Genç, 2018: 170).

Araştırmanın amacı, sağlık çalışanlarının iş özerkliğinin iş performasına etkisinde örgütsel sinizmin ve yaşam tatmininin seri-çoklu aracı etkisini araştırmaktır. Literatürde örgütsel sinizmin iş performansına etkisini inceleyen çalışmalar (Bacaksız vd., 2018: 55; Çiçek vd., 2018: 32; Kahya, 2013: 42) ve yaşam tatmininin iş performansına etkisini inceleyen çalışmalar (Çınar ve Özyılmaz, 2018: 143; Jones, 2006: 33; Kale, 2015: 114; Özyılmaz, 2018: 64) bulunmaktadır. Ancak, literatür taramasında iş özerkliğinin iş performansına (Çekmecelioğlu ve Günsel, 2011: 893; Kuvaas, Buch ve Dysvik, 2016: 16; Pekdemir, Koçoğlu ve Gürkan, 2014) ve örgütsel sinizme (Kwantesa ve Bond, 2019: 6; Naus, Iterson ve Roe, 2007: 53) etkisini araştıran az çalışamaya rastlanmıştır. Ayrıca, iş özerkliğinin yaşam tatminine etkisini araştıran (Coad ve Binder, 2014: 8; De Cuyper ve De Witte, 2006: 443) ve örgütsel sinizmin yaşam tatminine etkisini araştıran (Aslan ve Yılmaz, 2013 : 590; Cazan ve Năstasă, 2015: 1577; Çivilidağ, 2015: 278; Kasalak, 2019: 331; Mehdinezhad, 2015: 259) çok az sayıda çalışmaya rastlanmıştır. Daha önce yapılan çalışmalarda sözkonusu değişkenler (iş özerkliği, iş performansı, örgütsel sinizm ve yaşam tatmini) arasındaki ilişkiler incelenmiş, ancak bu değişkenler arasında seri-çoklu aracılık ilişkileri incelenmemiştir. Dolayısıyla, mevcut çalışma ile literatüre katkı sağlanacağı düşünülmektedir. Ayrıca, hayati tehlikesi olan ve hata kabul etmeyen sağlık kuruluşlarındaki çalışanların iş özerklikliği, iş performansı ve yaşam tatminlerinin yüksek, örgütsel sinizm düzeylerinin ise düşük olması çalışanların hastalara anında müdahale etmesi, hayat kurtarması ve hasta memnuniyetinin sağlanması açısından oldukça önemlidir. Dolayısıyla, örneklemin sağlık çalışanlardan seçilmiş olması ve iş özerkliği ile iş performansı ilişkisinde örgütsel sinizmin ve yaşam tatmininin seri-çoklu aracılık etkisini araştıran çalışmaya rastlanmamış olması mevcut çalışmanın özgün olduğunu göstermektedir. 


\section{KAVRAMSAL ÇERÇEVE VE HIPOTEZLER}

\section{1. $\dot{I}_{s ̧}$ Özerkliği}

Otonomi (Özerklik), bir bireyin veya ekibin bir fikri, bir hedefi veya bir vizyonu ortaya koymada ve başarmada bağımsız olarak hareket etmesini ifade etmektedir (A ̆gca ve Kurt, 2007: 96). Noam (2001) tarafından özerklik "bireyin her mesafesindeki, yakın ya da uzak, açık yada dolayımlı, psiko-sosyal, sosyopolitik ve kültürel çevresinin ona uyguladığı baskıdan azade alabilme yetisini kazanıp, özgür ve bağımsız karar verebilmesi ve yaşamında bunu içselleştirmesi edimi" olarak ifade edilmektedir (Aktaran: Armağan, 2013: 55). İş özerkliği ise, işin planlanmasında, yürütülmesinde, kullanılacak yöntemin belirlenmesinde çalışanlara önemli derecede özgürlük, bağımsızlık ve karar verme yetkisi sağlaması olarak tanımlanmaktadır (Saragih, 2011: 205). Başka bir tanıma göre iş özerkliği, çalışanların yapacakları işi/işleri planlarken ve çalışırken sahip oldukları serbestlik derecesini ifade etmektedir (Bozgül, 2018: 23). Bireyler çalışma arkadaşları ile beraber çalışacakları için özerklik tam anlamıla bir serbestlik durumu değildir. Özerklik, işin süresi ve içeriği, çalışma araçları, çalışma şekillerinin belirlenmesi ve uygulanması açısından kontrol edilebilir olmalıdır (Ilyash vd., 2019:11). Eğer, bir işyerinde kontrol ve düzeltme unsurları baskın ise, o işyerinde iş özerkliği sözkonusu değildir. İş özerkliğinin olmadığı veya düşük olduğu iş yerlerinde çalışanlar bir süre sonra düşüncelerinde, duygularında ve davranışlarında kendilerini baskı altında hissedeceklerdir (Çinko ve Utaş, 2017: 54). Çalışanlarına yeterli iş özerkliği sağlayan yani işle ilgili görevlerini yerine getirirken karar verme becerilerini kullanabilme olanağı veren bir işyerinde ise (Lin ve Ping, 2016: 2), çalışanların bilgilerini, tecrübelerini, becerilerini ve yaratıcllıklarını ortaya çıkarmalarında artış söz konusu olacaktır (Çinko ve Utaş, 2017: 54). İş özerkliğinin yüksek olması, çalışanların motivasyonunu (Çinko ve Utaş, 2017), iş performansını (Dysvik ve Kuvaas, 2010; Saragih, 2011), iş tatminini (Çolak vd., 2017; Doğan ve Can, 2009; Saragih, 2011), örgüte bağlılığını (Naqvi, Ishtiaq, Kanwal ve Ali, 2013), örgütle özdeşleşmesini (Özkoç, 2016) artırırken; çalışanların iş stresi (Saragih, 2011: 210-212), sinik davranışları, işe yabancılaşma ve işten ayrılma niyeti (Özkoç, 2016; Shahzad, 2016; Yen-Ju Lin vd., 2011) gibi istemeyen durumları da azaltmaktadır.

\section{2. İş Özerkliği ve İş Performansı İlişkisi}

Performans, bireylerin görevlerini yerine getirebilmek için harcadıkları çabaların karşısında elde ettikleri başarı düzeyi olarak ifade edilmektedir (Begenirbaş ve Turgut, 2014: 137). Performans, bireylerin veya kurumların bir faaliyette hedefe ulaşma derecesidir. İş gören performansı ise, çalışanların alacakları ücret karşılığında göstermeleri gereken çabayı ifade etmektedir (Akdemir ve Duman, 2016: 345). İş performansı, hem bireyler hem de işletmeler açısından büyük bir öneme sahiptir (Sonnentag vd., 2008: 427). Görevlerini gereği gibi yerine getiren ve işinde yüksek başarı gösteren çalışanlar, orta veya düşük performans gösteren çalışanlara göre daha iyi kariyer fırsatları elde ederler. Ayrıca, yüksek performans gösteren çalışanlar yüksek gelir, ödüllendirme ve sosyal itibar gibi avantajlar da elde ederler. Yüksek performans gösteren çalışanlar sayesinde işletmelerin amaç ve hedeflerine ulaşabilmeleri, faaliyet gösterdikleri sektör içinde rekabet gücü kazanabilmeleri ve başarılı olabilmeleri mümkün olabilmektedir (Ranaweera ve Dharmasiri, 2016: 47; Sonnentag vd., 2008: 427; Yelboğa, 2006:200). Dolayısıyla, bir işletme ancak çalışanının sergilediği performans düzeyi kadar belirlenen amaçlara ve hedeflere ulaşabilir. Çalışanlar, işlerinde ne kadar yüksek performans gösterirlerse, işletmenin sonuçlarıda o kadar yükselecek ve müşteri memnuniyeti de o kadar artacaktır. Bu durum işletmenin gelirinin artmasına ve pazar payının büyümesine neden olacaktır (Genç, 2018: 170).

Çalışanın iş performansına birçok faktör etki etmektedir. Yapılan çalışmalarda iş performansına sinizim (Uysal ve Yıldız, 2014), algılanan örgütsel destek (Rhoades ve Eisenberger, 2002), duygusal zeka ve yaşam tatmini (Çınar ve Özyılmaz, 2018), örgütsel bağlılık (Akyüz ve Eşitti, 2015) gibi birçok örgütsel faktörün etkisi olduğu tespit edilmiştir. Çalışanın performansı üzerine etki eden diğer bir faktör de iş özerkliğidir. İş özerkliğinin sağlandığı işletmelerde, çalışanların performans düzeylerinde artış gerçekleşecektir. (Kutaniş, 2018: 67). Literatürdeki çalışmalarda iş özerkliği ile iş perfomansı arasında pozitif bir ilişki olduğu yönündedir. Saragih (2011: 210-212) yaptı̆̆ı çalışmada, iş özerkliği, iş performansı, iş tatmini ve iş stresi değişkenleri arasındaki ilişkileri incelemiş ve bu ilişkide özyeterliliğin aracı etkisini araştırmıştır. Araştırma, bir devlet üniversitesinde MBA programında eğitim gören öğrenciler ile farklı şirketlerde çalışan bireyler üzerinde gerçekleştirilmiştir. Araştırma sonucunda; iş özerkliğinin iş tatmini ve iş performansını olumlu olarak etkilediği sonucuna ulaşmıştır. Araştırmanın diğer sonuçlarına göre, özyeterliliğin iş özerkliği ile iş performansı arasındaki ilişkide ve iş özerkliği ile iş tatmini arasındaki ilişkide kısmı aracı etkisinin olduğunu 
tespit etmiş̧ir. Pekdemir vd. (2014) yaptıkları araştırmada çalışan performansı ile özerklik ve ödüllendirme algısı arasındaki ilişkide çalışanın inovasyona yönelik davranışının aracı etkisini incelemeyi amaçlamışlardır. Araştırmanın sonucunda, ödüllendirme algısı ile çalışan performansı arasındaki ilişkide çalışanın inovasyona yönelik davranışının kısmi aracı etkisinin olduğunu; özerklik algısının çalışan performansı üzerinde anlamlı bir etkisinin olduğunu; özerklik algısı ile çalışan performansı arasındaki ilişkide çalışanın inovasyona yönelik davranışının tam aracı etkisinin olduğunu saptamışlardır. Literatürdeki diğer çalışmalarda da iş özerkliği iş performansını anlamlı ve olumlu olarak etkilediği sonucuna ulaşılmıştır (Çekmecelioğlu ve Günsel, 2011: 893; Khan vd., 2012: 2703; Kuvaas vd., 2016: 16).

H1(a): Sağlık çalışanlarının iş özerkliğinin iş performansı üzerinde pozitif yönlü ve istatistiksel olarak anlamlı etkisi vardır.

\section{3. İş Özerkliği, İş Performansı ve Örgütsel Sinizm Arasındaki İlişki}

Bireylerin sadece kendi çıkarlarını gözettiğini düşünen ve buna göre herkesi çıkarcı olarak kabul eden kişiye "sinik" ve bu durumu açıklamaya çalışan düşünceye ise "sinizm" denir (Yavuz ve Bedük, 2016: 302). Günümüzde sinizm, "bireyleri zor beğenen, memnuniyetsiz, olaylara sürekli eleştirel yaklaşan, menfaat düşkünü ve olumsuz düşüncelerle dolu varlıklar" olarak tanımlanmaktadır (Torun ve Çetin, 2015: 138). Sinizm, insan davranışı ile ilgili genellikle olumsuz algıları yansıtan, doğuştan gelen ve kararlı bir kişilik özelliğini ifade etmektedir (Tokgöz ve Yılmaz, 2008: 285). Sinizm, sadece toplumu etkileyen bir tutum değildir. Bunun yanında, örgütleri de etkileyen olumsuz bir tutumdur. Sinizm, bir kurumda veya işletmede gerçekleşiyorsa, örgütsel sinizm olarak ifade edilmektedir (Yıldırım ve Akın, 2018: 428). Genel sinizm kişinin kişiliğinden kaynaklanırken, örgütsel sinizm çalışanın sinik tutum sergilemesine neden olan örgütsel unsurlardan kaynaklanmaktadır (Tokgöz ve Yılmaz, 2008: 285). Dean, Brandes ve Dharwadkar (1998) göre, örgütsel sinizm bireyin istihdam edildiği kuruma/örgüte karşı, üç boyuttan (bilişsel boyut: çalışanın örgütün bütünlükten yoksun olduğuna dair inancı, duyuşsal boyut: çalışanın örgüte ilişkin olumsuz duyguları ve davranışsal boyut: çalışanın örgüte karşı aşağılayıcı ve eleştirel davranışlarda bulunma eğilimi) oluşan olumsuz tutumunu ifade etmektedir (Dean, Brandes ve Dharwadkar, 1998: 345). Örgütsel sinizm, çalışanın çalıştığı örgütün güvenilir olmadığını hissetmesi ve dürüstlükten yoksun olduğunu düşünmesidir (Kerse ve Karabey, 2019: 88; Durrah, Chaudhary ve Gharib, 2019: 3).

Örgütsel sinizm, kişilik özellikleri, beklenti, atfetme, tutum, sosyal değişim, durumsal ve sosyal bilişsel yaklaşımları temeline dayanmaktadır (Tokgöz, 2011: 363).

Örgütsel sinizmin ortaya çıkmasında etken olan örgütsel unsurlar; yanlış yönetilen değişim çabaları, aşırı stres, rol çatışması, kişisel ve örgütsel beklentilerin karşılanmaması, sosyal destek yetersizliği, iletişimin düşük olması, psikolojik sözleşme ihlalleri, işten çıkarılma, terfi olanaklarının yetersizliği, düşük liderlik özelliklerine sahip olma, aşırı şüphecilik, yüksek endişe, içe dönüklük, aşırı iş yükü, negatif duygusallık, düşük maaş gibi unsurlardır (Altınöz vd., 2011: 290). Ayrıca, iş özerkliğinin eksikliği de örgütsel sinizme neden olmaktadır (Shaharruddin ve Ahmad, 2015: 91). Örgütsel sinizm sonucunda, çalışanlarda depresyon, uykusuzluk, duygusal çöküntü, hayal kırıklığı yaşama, öfke duyma, dargınlık, hiddetlenme, gerilim, endişe, alkol ve sigara kullanımı/artışı, işe yabancılaşma, tükenmişlik, işten ayrılma niyeti, işten ayrılma gibi bir çok olumsuzlukların yaşanmasına neden olmaktadır. Ayrıca, çalışanlarda iş performansı, örgütsel bağlılık, iş tatmini, verimlilik ve motivasyon düzeylerinde de bir düşüş yaşanmaktadır. Dolayısıyla, örgütsel sinizm işletmeler açısından istenmeyen sonuçları olan bir tutumdur (Kalağan, 2009: 40; Yıldırım ve Akın, 2018: 431). Bu istenmeyen sonuçların azaltılması için, işletmeler çalışanlarına örgütsel olarak destek vermeli ve belli düzeylere kadar onlara özerklik tanımalıdırlar.

İşyerinde özerk çalışma olanağına sahip olan çalışanlar yaptıkları faaliyetlerde daha özgür davranacaklar ve sıkı kontroller ile karşı karşıya kalmamış olacaklardır. Bunun sonucunda çalışanlarda sinik davranışlar azalacaktır (Shaharruddin ve Ahmad, 2016: 3). Dolayısıyla örgütsel sinizm ile iş özerkliği arasında negatif ilişki bulunmaktadır. Shaharruddin ve Ahmad (2015: 95) Malezya'nın göçmenlik bürosunda çalışan 60 memura yönelik yaptıkları çalışmada iş özerkliğinin örgütsel sinizm üzerindeki etkisini tespit etmeyi amaçlamışlardır. Araştırma sonucunda iş özerkliğinin örgütsel sinizm üzerinde negatif etkisi olduğu sonucuna ulaşmışlardır. Yapılan başka çalışmalarda da iş özerkliği örgütsel sinizmi olumsuz olarak etkilediği sonucuna ulaşılmıştır (Çiçek vd., 2018: 32; Kwantesa ve Bond, 2019: 6; Naus vd., 2007: 53). Bu doğrultuda çalışmanın ikinci hipotezi aşağıdaki gibi geliştirilmiştir. 
H1(b): Sağlık çalışanlarının iş özerkliğinin bilişsel sinizm düzeyleri üzerinde negatif yönlü ve istatistiksel olarak anlamlı etkisi vardır.

H1(c): Sağlık çalışanlarının iş özerkliğinin duyuşsal sinizm düzeyleri üzerinde negatif yönlü ve istatistiksel olarak anlamlı etkisi vardır.

H1(d): Sağlık çalışanlarının iş özerkliğinin davranışsal sinizm düzeyleri üzerinde negatif yönlü ve istatistiksel olarak anlamlı etkisi vardır.

Örgütsel sinizm yaşayan çalışanların iş performans düzeylerinde düşme gerçekleşmektedir. Dolayısıyla örgütsel sinizm ile iş performansı arasında negatif bir ilişki bulunmaktadır (Genç, 2018: 170). Yani, çalışanlarda örgütsel sinizm düzeyi artıkça iş performans düzeyi düşmektedir. Akdemir, Kırmızıgül ve Zengin (2016: 128) tarafından yapılan çalışmada Tunceli ve Kafkas üniveristelerinde çalışan idari, akademik ve geçici işlerde çalışanların örgütsel sinizim ve iş performası ilişkilerini test etmeyi amaçlamışlardır. Yapılan çalışmanın sonucunda iki değişken arasında negatif ilişkinin olduğunu tespit etmişlerdir. Çotul ve Altındağ (2018: 1208) İstanbul'da tekstil sektöründe ki çalışanlara yönelik yaptıkları çalışmada, işletmenin etik dışı kararları sonucunda çalışanlarda sinik davranışlara neden olup olmadığı ve sinik tutumların çalışanların iş performansını nasıl etkilediğini test etmeyi amaçlamışlardır. Araştırmanın sonucunda, işletme yönetiminin etik dışı karar almaları çalışanların sinik davranışlarını artırdığı sinik tutuma sahip olan çalışanların da iş performanslarının azaldığı sonucuna ulaşmışlardır. Yapılan diğer çalışmalarda da örgütsel sinizm ve boyutlarının (bilişsel, duyuşsal ve davranışsal) iş performansını negatif ve anlamlı olarak etkilemekte olduğu tespit edilmiştir (Bacaksız vd., 2018: 55; Brandes ve Das, 2015: 255; Çiçek vd., 2018: 32; Genç, 2018: 178; Kahya, 2013: 42; Şantaş vd., 2016: 879; Uysal ve Yıldız, 2014: 846). Kavramsal çerçeve ve daha önce yapılan çalışmaların sonucunda örgütsel sinizmin iş performansını negatif olarak etkilediği düşünülmektedir. Bu doğrultuda araştırmanın üçüncü hipotezi geliştirilmiştir.

H1(e): Sağlık çalışanlarının bilişsel sinizm düzeylerinin iş performansları üzerinde negatif yönlü ve istatistiksel olarak anlamlı etkisi vardır.

H1(f): Sağlık çalışanlarının duyuşsal sinizm düzeylerinin iş performansları üzerinde negatif yönlü ve istatistiksel olarak anlamlı etkisi vardır.

H1(g): Sağlık çalışanlarının davranışsal sinizm düzeylerinin iş performansları üzerinde negatif yönlü ve istatistiksel olarak anlamlı etkisi vardır.

Kavramsal çerçeveye ve literatürdeki çalışmalara göre, iş özerkliği, iş performansı ve örgütsel sinizm değişkenleri arasında anlamlı ilişkiler bulunmaktadır. Buna göre, işlerinde özerk olan çalışanların bir taraftan iş performanslarında artış diğer taraftan sinik tutumlarında azalış beklenmektedir. Ayrıca, çalışanların örgütsel sinizm düzeylerinin azalması durumunda, iş performanslarının artması beklenmektedir. Dolayısıyla, çalışanların iş özerklikliğinin iş performansına etkisinde örgütsel sinizmin aracı etkisinin olduğu düşünülmektedir. Bu düşünce doğrultusunda aşağıdaki hipotez geliştirilmiştir.

H1(h): Sağlık çalışanlarının iş özerkliğinin iş performansına etkisinde bilişsel sinizmin aracı etkisi vardır.

H1(1): Sağlık çalışanlarının iş özerkliğinin iş performansına etkisinde duyuşsal sinizmin aracı etkisi vardır.

H1(i): Sağlık çalışanlarının iş özerkliğinin iş performansına etkisinde davranışsal sinizmin aracı etkisi vardır.

\section{4. İş Özerkliği, İş Performansı, Örgütsel Sinizm ve Yaşam Tatmini Arasındaki İlişki}

Yaşam, bireyin hem iş yerinde hem de iş dışında geçirdiği zamanı ifade etmektedir (Pekel, Karaoğlu ve Atar, 2016: 386). Yaşam tatmini, kişinin yaşama karşı göstermiş olduğu tutumudur (Kale, 2015: 107). Başka bir tanıma göre, yaşam tatmini bireyin ne istediği ve neye sahip olduğu ile ilgili bir kavramdır. Bireyin istedikleriyle sahip oldukları arasındaki fark ne kadar az ise bireyin yaşam tatmini o kadar yüksek olacak, aksi takdirde bireyin yaşam tatmini azalacaktır (Çınar ve Özyılmaz, 2019: 541). Kişilerin istek ve ihtiyaçlarının farklı olması nedeniyle, yaşam tatmini kişiden kişiye farklılık gösteren göreceli bir kavramdır (Çınar ve Özyılmaz, 2018: 133). Bu durum bazı faktörlerin etkisinde gerçekleşmektedir. Kişilerin yaşam tatminlerini etkileyen kişisel faktörler (yaş, cisiyet, eğitim durumu gibi kişisel faktörler, kişilerin negatif veya pozitif duygusallıkları, beklentileri gibi faktörler), çevresel faktörler (alternatif iş bulma imkanları), toplumsal faktörler (sosyal ağlar, hemşehrilik duygusu, üye oldukları sosyal gruplar, sosyal etkinliklere katılabilme gibi 
faktörler) ve iş ile ilgili faktörler (işin niteliği, ücret/gelir, işte başarılı olma, çalışanın örgütteki rolü, iş yükü, yükselme imkanları, örgütte verilen eğitimler, özerklik, sinizim gibi faktörler) bulunmaktadır (Aslan ve Yılmaz, 2013 : 590; Coad ve Binder, 2014; Çivilidağ, 2015; Özdevecioğlu ve Aktaş, 2007: 8; Yıldırım ve Demirel, 2015: 141).

Bir işyerinde çalışanlara yüksek düzeyde özerklik tanılıyorsa, çalışanların hem iş tatmini hem de yaşam tatmini artış gösterecektir. Dolayısıyla, iş özerkliği ile yaşam tatmini arasında pozitif bir ilişki bulunmaktadır (Coad ve Binder, 2014: 8). Daha önce yapılan çalışmalarda da iş özerkliğinin yaşam tatmini üzerinde olumlu etkisi olduğu yönündedir (Coad ve Binder, 2014: 8; De Cuyper ve De Witte, 2006: 443).

H1(k): Sağlık çalışanlarının iş özerkliğinin yaşam tatminleri üzerinde pozitif yönlü ve istatistiksel olarak anlamlı etkisi vardır.

Çalışanlar, iş yerinde yaşadıkları olumsuzluklar gibi iş dışında da olumsuzluklar ile karşı karşıya gelmektedirler. Çalışanların, iş dışında yaşadıkları bir takım olumsuzluklar (tatil gibi etkinliklere zaman ayırmama, yeterli uyku uyumama, ailevi sorunlar, sağlık problemleri, ölüm, ayrılık gibi) onların yaşam tatminini olumsuz yönde etkileyebilmektedir. Yaşam tatminine ulaşamayan çalışanlar günlük yaşantılarında mutsuz olmakta, kendilerini huzursuz hissetmekte ve konsantrasyon sorunları yaşamaktadırlar. Böylece, uzun sürede çalışanların kendilerini toparlamaları ve işe tam olarak konsantre olmaları sözkonusu olmayacak ve iş performanslarında düşüş yaşayacaklardır (Pekel vd., 2016: 386; Uludağ, 2019: 292). Dolayısıyla yaşam tatmini ile iş performansı arasında pozitif yönlü bir ilişki bulunmaktadır. Daha önce yapılan çalışmalarda da yaşam tatmininin iş performansını olumlu yönde etkilediği tespit edilmiştir (Çınar ve Özyılmaz, 2018: 143; Jones, 2006: 33; Kale, 2015: 114; Özyılmaz, 2018: 64; Rode vd., 2005: 428; Uludağ, 2019: 298).

H1(l): Sağlık çalışanların yaşam tatminlerinin iş performansı üzerinde pozitif yönlü ve istatistiksel olarak anlamlı etkisi vardır.

Kavramsal çerçeve ve literatürdeki çalışmalar, iş özerkliği, iş performansı ve yaşam tatmini değişkenleri arasında anlamlı ilişkiler bulunmaktadır. Çalışanlarda iş özerkliğinin yükselmesi yaşam tatmininin yükselmesine, yaşam tatmininin yükselmesi iş performansının yükselmesine neden olmaktadır. Buradan yola çıkarak, iş özerklikliğinin iş performansına etkisinde yaşam tatmininin aracı etkisinin olabileceği düşünülmüş ve aşağıdaki hipotez geliştirilmiştir.

H1(m): Sağlık çalışanlarının iş özerkliğinin iş performansına etkisinde yaşam tatmininin aracı etkisi etkisi vardır.

Bireyler, hayatlarının büyük bir bölümünü işyerinde geçirmekte ve iş dışında da iş yerlerini düşünmektedirler. İş yerinde yaşanan mutsuzluklar, hayal kırıklıkları, isteksizlikler, tatminsizlikler, çalışma arkadaşlarıyla yaşanan olumsuzluklar, aşırı stres, kötü iletişim, bireysel ve örgütsel olarak beklentilerin karşılanmaması gibi unsurlar çalışanlarda sinik davranışlara neden olmaktadır. Bu durum çalışanın hem iş yaşamını hem de iş dışı yaşamını olumsuz yönde etkileyerek, çalışanın yaşam tatmininin düşmesine neden olmaktadır. Yaşam tatmininin düşmesi çalışanın bir yandan yöneticileriyle, iş arkadaşlarıyla, ailesiyle ve çevresiyle olan ilişkilerini olumsuz yönde etkilerken, diğer yandan da fiziksel ve ruhsal sağlı̆̆ını bozabilmektedir (Akgündüz, 2013: 183; Altınöz vd., 2011: 290; Özyer vd., 2015: 264). Bu doğrultuda, örgütsel sinizm ile yaşam tatmini arasında ters yönde bir ilişki bulunmaktadır. Literatürde ki çalışmalarda, çalışanlarda örgütsel sinizmin artması yaşam tatminlerinin düşmesine neden olduğu yönündedir (Aslan ve Yılmaz, 2013 : 590; Çivilidağ, 2015: 278; Kasalak, 2019: 331). Buna göre aşağıdaki hipotez önerilmiştir.

H1(n): Sağlık çalışanlarının bilişsel sinizm düzeylerinin yaşam tatmini üzerinde negatif yönlü ve istatistiksel olarak anlamlı etkisi vardır.

H1(o): Sağlık çalışanlarının duyuşsal sinizm düzeylerinin yaşam tatmini üzerinde negatif yönlü ve istatistiksel olarak anlamlı etkisi vardır.

H1(ö): Sağlık çalışanlarının davranışsal sinizm düzeylerinin yaşam tatmini üzerinde negatif yönlü ve istatistiksel olarak anlamlı etkisi vardır.

Araştırma konusunu oluşturan iş özerkliği, örgütsel sinizm, iş performansı ve yaşam tatmini değişkenleri arasındaki neden-sonuç ilişkilerinin "sosyal değişim teorisi" ile ilişkilendirilebileceği düşünülmektedir. 
Sosyal Değişim Kuramı (Blau, 1964), bireyin beklentileri doğrultusunda zihninde yaptığı ödül ile bedel arasındaki değerlendirme sonucunda akılcı bir seçim yapma sürecini ifade etmektedir (Yıldırım ve Acar, 2018: 271). Sosyal Değişim Kuramı, genellikle etkileşimlerin ve işlemlerin birbirine bağlı olduğu ve başka birinin eylemlerine bağlı olarak ortaya çıktığı görüşü hakimdir (Engin, 2015: 19). Kuram, sosyal değişimlerdeki insan davranışlarını açıklamak üzere geliştirilmiştir. Kuramın en temel ilkesi "karşıllklılık normu" ilkesidir. Karşılıklılık normu ilkesine göre, sosyal değişimlerde bir bireye olumlu bir davranışta bulunulduğunda, bu birey görmüş olduğu olumlu davranışa karşı kendisi de karşılığında olumlu davranış gösterme eğilimi içerisinde olacaktır. Sosyal değişim kuramı, işyeri davranışlarını anlamak için en etkili kavramsal paradigmalardandır (Bahar, 2019: 240). Bu kuram işletmeler açısından, çalışanlar ile işletme arasında var olan ancak net olarak belli olmayan, ihlal edildiğinde önemli olumsuz sonuçlar ortaya çıkaran beklentilerle ilişkili karşılıklı zorunluluklardır (Turunç ve Çelik, 2010: 212; Taştan, İşçi ve Arslan, 2014: 123). Bu teoriye göre, çalışanların işlerinde gösterecekleri çabaları ve performansları, işletmenin gelecekte sağlamasını bekledikleri maddi ve manevi ödüllere bağlı olarak biçimlendirirler (Turunç ve Çelik, 2010: 212). Ayrıca, çalışanlar işletmeden maddi ve manevi destek aldıklarına dair algılarının artması durumunda, işletme ile çalışan arasındaki karşılıklı ilişkinin yani etkileşimin kalitesinin yükselmesine neden olacaktır. Böylece çalışanların işletmeye/işyerine karşı geliştirdiği sinik davranışların azalması beklenmektedir (Özkara vd., 2019: 103). Beklentilerin karşılanması ve uygun çalışma şartlarının olması, çalışanların yaşam tatmininin artmasına neden olabilir. İş yaşamına bağlı olarak yaşam tatmini yüksek olan çalışanların iş performansının da yüksek olması beklenmektedir (Yıldırım ve Acar, 2018: 272). Dolayısıyla, işveren çalışanlarına ne kadar fazla özerklik tanırsa, çalışanların o kadar fazla performanslarının ve yaşam tatminlerinin artması, örgütsel sinizm düzeylerinin azalması mümkün olabilecektir. Ayrıca, örgütsel sinizm düzeyleri azalan çalışanların sosyal değişim teorisine göre, iş performanslarının ve yaşam tatminlerinin artması mümkün olabilecektir.

İlgili literatürdeki çalışmaların bulguları göstermiştir ki, iş özekliği, örgütsel sinizm, iş performansı ve yaşam tatmini değişkenleri arasında anlamlı düzeyde ilişkiler bulunmaktadır. Daha önce kavramsal çerçeve ve yapılan çalışmalara göre, iş özerkliği ile iş performansı arasındaki ilişkide, örgütsel sinizmin ve yaşam tatmininin aracı etkiye sahip olabileceği düşünülmüştür. Buna bağlı olarak aşağıdaki hipotez oluşturulmuş ve araştırma modeli Şekil 1'de sunulmuştur.

H1(p): Sağlık çalışanlarının iş özerkliği ile iş performansı arasındaki ilişkide bilişsel sinizmin ve yaşam tatmininin seri-çoklu aracılık etkisi vardır.

H1(r): Sağlık çalışanlarının iş özerkliği ile iş performansı arasındaki ilişkide duyuşsal sinizmin ve yaşam tatmininin seri-çoklu aracılık etkisi vardır.

H1(s): Sağlık çalışanlarının iş özerkliği ile iş performansı arasındaki ilişkide davranışsal sinizmin ve yaşam tatmininin seri-çoklu aracılık etkisi vardır.

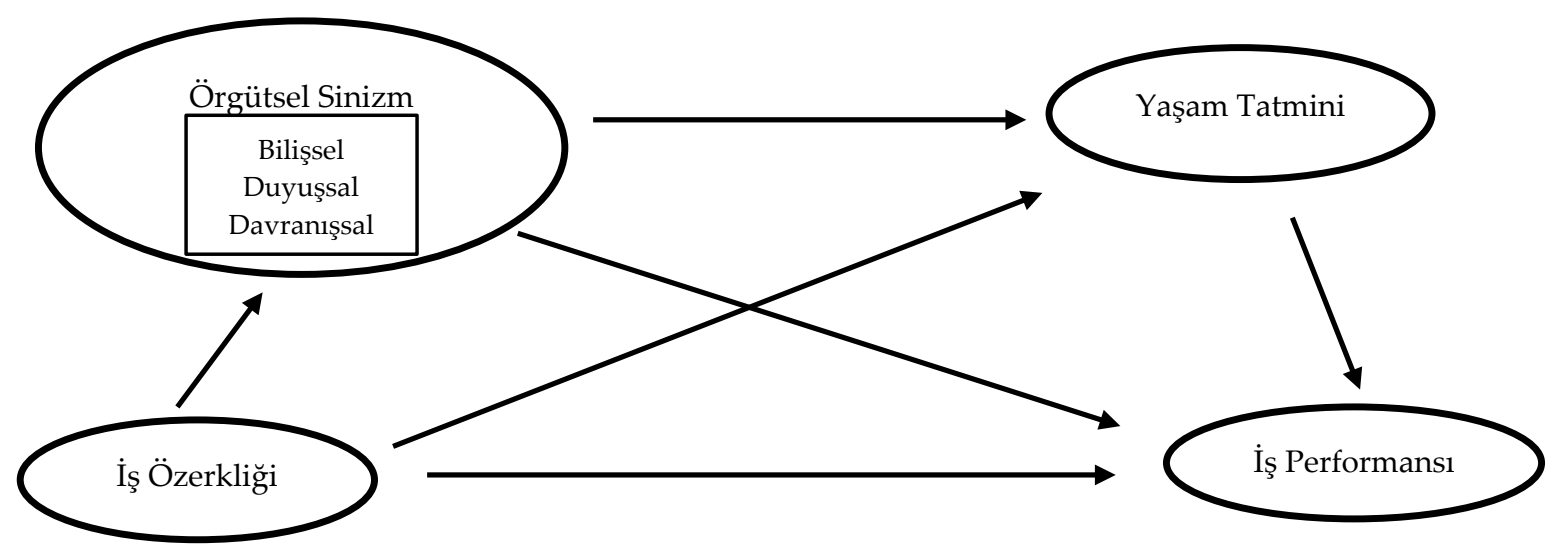

Şekil 1. Araştırmanın Modeli 


\section{ARAŞTIRMANIN YÖNTEMI}

\subsection{Araştırmanın Örneklemi}

Araştırma, Kırklareli ilinde faaliyet gösteren üç özel hastanede ki çalışanlar üzerinde gerçekleştirilmiştir. Araştırma Kasım 2019-Ocak 2020 arasında yapılmıştır. Araştırmaya katılan üç hastaneden alınan bilgilere göre, toplamda 290 sağlık çalışanı bulunmaktadır. Ana kütleden \%95 güvenilirlik sınırları içerisinde \%5’lik hata payı dikkate alınarak örneklem büyüklüğü 151 kişi olarak hesaplanmıştır. Bu kapsamda, olasılıklı olmayan örneklem tekniğinden kolayda örnekleme yöntemi kullanılmıştır. Kolayda örnekleme; araştırılacak konu için ihtiyaç duyulan büyüklükteki örnekleme ulaşılıncaya kadar en kolay ve ulaşılabilecek deneklerden veri toplanması suretiyle yapılan örnekleme tekniğidir. Örneğin; öğrenciler üzerine araştırma yapmak isteyen bir araştırmacının sadece dersine girdiği veya kolay ulaşabileceği öğrencileri örneklem olarak seçmesidir (Gürbüz ve Şahin, 2014: 128-130). Dağıtılan anketlerden 160'1 geri dönmüş, ancak 7 anket katılımcllar tarafından eksik doldurulması sonucunda 153 anket kabul edilebilir nitelikte bulunmuştur. Bu nedenle, araştırmanın örneklemini 153 kişi oluşturmaktadır.

Araştırmaya katılanların \%76,5'i (n=117) kadın ve \%23,5'i (n=36) erkeklerden oluşmaktadır. Katılımcıların yaş gruplarına göre dağılımları \%86,9'u (n=133) 19-39 yaş aralığında, \%10,5'i (n=16) 40-54 yaş aralı̆̆ında ve \%2,6'sı $(n=4) 55$ ve üzeri yaş aralığında olduğu; \%67,3'ünün ( $n=103)$ evli ve \% 32,7'sinin $(n=50)$ bekar olduğu; eğitim durumuna göre \%35,9'u (n=55) önlisans, \%35,6's1 (n=53) lise, \%20,9'u (n=32) lisans, \%4,6's1 (n=7) ilköğretim ve $\% 3,9^{\prime}$ u (n=6) lisans üstü eğitime sahip oldukları ve katılımcıların \%66'sı (n=101) 1-5 yıl arasında ve \% 29,4'ü $(\mathrm{n}=52)$ 6-10 yıl arasında çalıştıkları tespit edilmiştir. Araştırmaya katılan sağlık çalışanlarının yaklaşık yarısı (\%48,4 =74) normal, \%19'u (n=29) yüksek, \%17,6'sı (n=27) az, \%9,2'si (n=14) çok yüksek ve \%5,9'nun (n=9) çok az sosyal yaşama katıldıklarını belirtmişlerir.

\subsection{Araştırma Verilerinin Analizi}

Araştırmanın amacı doğrultusunda araştırma hipotezlerini test etmek için nicel araştırma yönteminden yararlanılmıştır. Veri toplama yöntemi olarak anket yönteminden yararlanılmıştır (5-tamamen katılıyorum, 1kesinlikle katılmıyorum). Araştırma sonucunda elde edilen veriler SPSS 20.0 ve Amos 20 paket programları yardımıyla analiz edilmiştir. Elde edilen verilerin normal dağılıma uygunluğunu test etmek için, çarpıklık (skewness) ve basıklık (kurtosis) katsayılarından yararlanılmıştır. Verilerin normal dağılıma sahip olması için skewness ve kurtosis değerlerinin -1 ile +1 aralığında olması gerekmektedir (Gürbüz ve Şahin, 2014: 210). Mevcut araştırmada iş özerkliği $(-0,510$ ve $-0,170)$, iş performansı $(-0,911$ ve 0,500$)$, örgütsel sinizm $(0,868$ ve $0,001)$ ve yaşam tatmini $(-0,605$ ve 0,164$)$ ölçeklerine ait çarpıklık ve basıklık değerleri -1 ile +1 değerleri arasında olduğu sonucuna ulaşılmıştır. Buna göre, ölçekler normal dağılıma sahiptir.

İş özerkliği, iş performansı, örgütsel sinizm ve yaşam tatmini ölçeklerinin yapısal geçerliliğini test edebilmek için keşfedici faktör analizinden (KFA), ölçeklerin güvenilirliklerini test edebilmek için Cronbach Alpha testinden ve ölçeklerin faktör yapısı ile uyumluluğunu test edebilmek için doğrulayıcı faktör analizinden (DFA) yararlanılmıştır. Değişkenlerin birbirleri ile ilişkilerini saptamak için korelasyon analizi, iş özerkliği ve iş performansı ilişkisinde örgütsel sinizmin ve yaşam tatmininin seri-çoklu aracı etkisini saptamak için Andrew F. Hayes'in (2013) geliştirdiği, bootstrap yöntemine dayanan IBM SPSS Process Makro uygulamasından yararlanılmıştır. Seri-çoklu aracı değişken modelinden model 6 kullanılmıştır. Bu modelde amaç, $X$ değişkeni (bağımsız değişken) ile $Y$ değişkeni (bağımlı değişken) arasındaki ilişkide $M 1$ değişkenin (birinci aracı değişken) ve M2 değişkenin (ikinci aracı değişken) aracılık etkisini araştırmaktadır (Hayes, 2013). Bu çalışmada iş özerkliği=bağımsız değişkeni; iş performansı= bağımlı değişkeni; örgütsel sinizm= birinci aracı değişkeni; yaşam tamini=ikinci aracı değişkeni ifade etmektedir.

\subsection{Araştırmanın Ölçekleri}

İş özerkliği ölçeği: Ölçek, ilk olarak Illardi, Kasser ve Ryan (1993) tarafından kullanışmış yedi madde ve tek boyuttan oluşmaktadır. Söz konusu ölçek, Tunç (2018) tarafından sağlık kurumlarında ki, çalışanlara yönelik yaptığı çalışmada kullanılmış olup, mevcut araştırmada da söz konusu ölçek kullanılmıştır (Tunç, 2018: 53). Ölçeğe, KFA yapılmış ve ölçekteki iki, dört ve altıncı soruların faktör yükleri 0,50'nin altında olması nedeniyle ölçekten çıkarılmış ve ölçek dört maddeye düşmüştür. Ölçekten faktör yükleri düşük olan sorular çıkarıldıktan sonra tekrar analiz yapılmış ve ölçek tek faktörde toplanmıştır. Elde edilen faktör ile toplam varyansın \%59,448'i açıklandığı görülmüştür. Maddelerin faktör yükleri 0,679-0,834 arasında olduğu 
saptanmıştır. Ölçeğe ilişkin Cronbach Alpha güvenilirlik katsayısının 0,767 olduğu tespit edilmiştir. Çıkan bu sonuca göre göre ölçek güvenilirdir. Ölçeğe ait uyum indeks değerlerinin $\left(X^{2} / \mathrm{df}=1,978, \mathrm{RMSEA}=0,08, \mathrm{NFI}=\right.$ 0,975, CFI=0,987, GFI=0,988, AGFI=0,939) uyum kriterlerini sağladığı tespit edilmiştir (Gürbüz ve Şahin, 2014: 329).

İş performansı ölçeği: Tek boyut ve 4 maddeden oluşan ölçek, 1999 yılında Kirkman ve Rosen'in yaptıkları çalışmada ve 2000 yılında Sigler ve Pearson'nın yaptıkları çalışmada kullanılmıştır. Ölçek, Türkçeye Çöl (2008) tarafından uyarlanmış geçerlilik ve güvenilirlikleri test edilmiştir (Uğur, 2017: 56). Ölçeğin, tek boyutlu olduğu ve toplam varyansın \%77,484'nü açıklandığı görülmüştür. Maddelerin faktör yükleri 0,83-0,93 arasında olduğu tespit edilmiştir. Elde edilen faktörlerle iş performansı ölçeğine ilişkin Cronbach Alpha güvenilirlik katsayısı 0,902 olarak bulunmuştur. Bu sonuca göre, ölçek yüksek güveniliğe sahiptir. Yapılan DFA sonucunda iş performansı öçeğine ait uyum indeks değerlerinin $\left(\mathrm{X}^{2} / \mathrm{df}=0,090\right.$, RMSEA=0,00, NFI=1,000, CFI= 1,000, GFI=1,000, AGFI=0,997) iyi uyum kriterlerini sağladığı tespit edilmiştir (Gürbüz ve Şahin, 2014: 329).

Örgütsel Sinizim Ölçeği; Çalışanların örgütsel sinizim düzeylerini ölçmek için Brandes, Dharwadkar ve Dean (1998) tarafından geliştirilen ve Kalağan (2009) tarafından Türkçeye uyarlanan 13 maddeden ve üç boyuttan (bilişsel, duyuşsal ve davranışsal) oluşan "örgütsel sinizm" ölçeği kullanılmıştır (Kalağan, 2009). Yapılan KFA sonucunda, soru 10 ve 11'in iki faktör yükü altında toplanması nedeniyle, ölçekten çıkarılmıştır. Ölçekten iki madde çıkarıldıktan sonra, tekrar KFA yapılmıştır. Ölçeğin üç faktörde toplandığı ve toplam varyansın \%81,463'ünü açıklandığı tespit edilmiştir. Madedelerin faktör yükleri bilişsel boyutun 0,789-0,846, duyuşsal boyutun 0,823-0,908 ve davranışsal boyutun 0,918-0932 arasında değerler aldığı saptanmıştır. Cronbach Alpha güvenilirlik katsayısı ölçeğin geneli için 0,908, bilişsel boyut için 0,908, duyuşsal boyut için 0,946 ve davranışsal boyut için 0,895 olarak saptanmış olup, örgütsel sinizm ölçeğinin yüksek bir güvenilirliğe sahip olduğu sonucuna ulaşılmıştır. Örgütsel sinizme ait birinci seviye DFA sonucunda, ölçeğe ait uyum endeks değerlerinin $\left(\mathrm{X}^{2} / \mathrm{df}=2,278, \mathrm{RMSEA}=0,09, \mathrm{NFI}=0,943, \mathrm{CFI}=0,967, \mathrm{GFI}=0,918, \mathrm{AGFI}=0,858\right)$ kabul edilebilir değerler aldığı sonucuna ulaşılmıştır (Meydan ve Şen, 2014: 37).

Yaşam tatmini ölçeği: Yaşam tatmini ölçeği, Diener, Emmons, Larsen ve Griffin (1985) tarafından geliştirilmiştir. Bu araştırmada kullanılan ölçek, Dağlı ve Baysal tarafından Türkçeye uyarlanmış, geçerlilik ve güvenilirlikleri test edilmiş, tek boyutlu ve beş madeden oluşmaktadır (Dağlı ve Baysal, 2016: 1254). Ölçeğin, tek boyutlu olduğu ve toplam varyansın \%68,533'nü açıklandığı görülmüştür. Maddelerin faktör yükleri 0,750,87 arasında olduğu tespit edilmiştir. Yaşam tatmini ölçeğine ilişkin Cronbach Alpha güvenilirlik katsayısı 0,884 olarak saptanmış olup, ölçeğin güvenilir olduğu sonucuna ulaşılmıştır. Yapılan DFA sonucunda yaşam tatmini öçeğine ait uyum indeks değerlerinin $\left(X^{2} / \mathrm{df}=1,929, \mathrm{RMSEA}=0,08, \mathrm{NFI}=0,976, \mathrm{CFI}=0,988, \mathrm{GFI}=0,975\right.$, AGFI=0,925) uyum kriterlerini sağladığı tespit edilmiştir (Gürbüz ve Şahin, 2014: 329).

\section{ARAŞTIRMANIN HIPOTEZ TESTLERINE İLIŞKİN ANALIZZ}

Ankete katılan sağlık çalışanlarının iş özerkliği, iş performansı, örgütsel sinizm boyutları (bilişsel, duyuşsal ve davranışsal) ve yaşam tatmini düzeylerine ait ortalama ve standart sapmaları Tablo 1'de verilmiştir. Sağlık çalışanlarına ait iş özerkliği, iş performansı ve yaşam tatmini düzeyleri ortalamanın üzerinde değerler almıştır. Sağlık çalışanlarının olumsuz duygularını ifade eden örgütsel sinizmin boyutları olan bilişsel, duyuşsal ve davranışsal sinizm düzeylerinin ise ortalama değerin altında değer aldığı gözlenmiştir.

İş özerkliği, iş performansı, örgütsel sinizm boyutları ve yaşam tatmini değişkenleri arasındaki ilişkileri test etmek için yapılan korelasyon analizi sonuçlarına göre, iş özerkliğinin iş performansı ile arasında $(r=0,368$, $\mathrm{p}=0,000)$ ve yaşam tatmini ile arasında $(\mathrm{r}=0,349, \mathrm{p}=0,000)$ pozitif yönde ve anlamlı bir ilişki olduğu sonucuna ulaşılmıştır. İş özerkliğinin, bilişsel sinizm düzeyleri ile arasında $(r=-0,257, p=0,001)$ ve duyuşsal sinizm düzeyleri ile arasında $(r=-0,371, p=0,000)$ negatif yönde ve anlamlı bir ilişki olduğu, ancak iş özerkliğinin davranışsal sinizim düzeyleri ile arasında $(\mathrm{r}=-0,143, \mathrm{p}=0,078)$ anlamlı bir ilişki olmadığı saptanmıştır. Sağlık çalışanlarının iş performansları bilişsel sinizm düzeyleri ile arasında $(\mathrm{r}=-0,178, \mathrm{p}=0,028)$, duyuşsal sinizm düzeyleri ile arasında $(r=-0,285 \mathrm{p}=0,000)$ ve davranıssal sinizim düzeyleri ile arasında $(r=-0,273, p=0,001)$ negatif ve anlamlı bir ilişkinin olduğu bulunmuştur. Diğer taraftan, iş performansı ile yaşam tatmini arasında $(\mathrm{r}=0,209, \mathrm{p}=0,009)$ pozitif yönde anlamlı bir ilişki olduğu tespit edilmiştir. Sağlık çalışanlarının yaşam tatminlerinin bilişsel sinizm düzeyleri ile arasında $(\mathrm{r}=-0,179, \mathrm{p}=0,026)$ ve duyuşsal sinizm düzeyleri ile arasında $(r=-0,225 \mathrm{p}=0,005)$ negatif ve anlamlı bir ilişkinin olduğu tespit edilirken, davranışsal sinizim düzeyleri ile arasında $(\mathrm{r}=-0,104, \mathrm{p}=0,201)$ anlamlı bir ilişki bulunanmamıştır. Bilişsel sinizm düzeylerinin 
duyuşsal sinizm düzeyleri ile arasında $(\mathrm{r}=0,594 \mathrm{p}=0,000)$ ve davranışsal sinizim düzeyleri ile arasında $(\mathrm{r}=0,269$, $\mathrm{p}=0,001)$, sağlık çalışanlarının duyuşsal sinizm düzeylerinin davranışsal sinizim düzeyleri ile arasında $(\mathrm{r}=0,391, \mathrm{p}=0,000)$ olumlu yönde anlamlı ilişki olduğu saptanmıştır (Tablo 1).

Tablo 1. İş Özerkliği, İş performansı, Örgütsel Sinizm ve Yaşam Tatmini Değişkenleri Arasındaki Korelasyon Analiz Sonuçları

\begin{tabular}{|l|c|c|c|c|c|c|c|c|}
\hline Değişken Ad1 & Ortalama & Standart Sapma & İÖ & İP & BS & DUYS & DAVS & YT \\
\hline ÏÖ & 3,761 & 0,896 & - & - & - & - & - & \\
\hline İP & 4,379 & 0,658 & $0,368^{* *}$ & - & - & - & - & - \\
\hline BS & 2,233 & 1,073 & $-0,257^{* *}$ & $-0,178^{*}$ & - & - & - & - \\
\hline DUYS & 1,505 & 0,869 & $-0,371^{* *}$ & $-0,285^{* *}$ & $0,594^{* *}$ & - & - & - \\
\hline DAVS & 1,592 & 1,023 & 1,143 & $-0,273^{* *}$ & $0,269^{* *}$ & $0,391^{* *}$ & - & - \\
\hline YT & 3,495 & 0,787 & $0,349^{* *}$ & $0,209^{* *}$ & $-0,179^{*}$ & $-0,225^{* *}$ & $-0,104$ & - \\
\hline
\end{tabular}

Not: ${ }^{* *}$ Korelasyon 0.01 düzeyinde anlamlı (iki yönlü). ${ }^{*}$ Korelasyon 0.05 düzeyinde anlamlı (tek yönlü).

İş özerkliği $=$ İÖ, İş Performansı=IP , Bilişsel Sinizm=BS, Duyuşsal Sinizim=DUYS, Davranışsal Sinizm=DAVS, Yaşam Tatmini=YT

İş özerkliğinin iş performansı üzerindeki etkisinde, bilişsel sinizmin ve yaşam tatmininin seri-çoklu aracılığını saptamak için Hayes (2013) tarafından önerilen bootstrap tekniği kullanılmıştır. Elde edilen bulgular Şekil 2'de sunulmuştur.

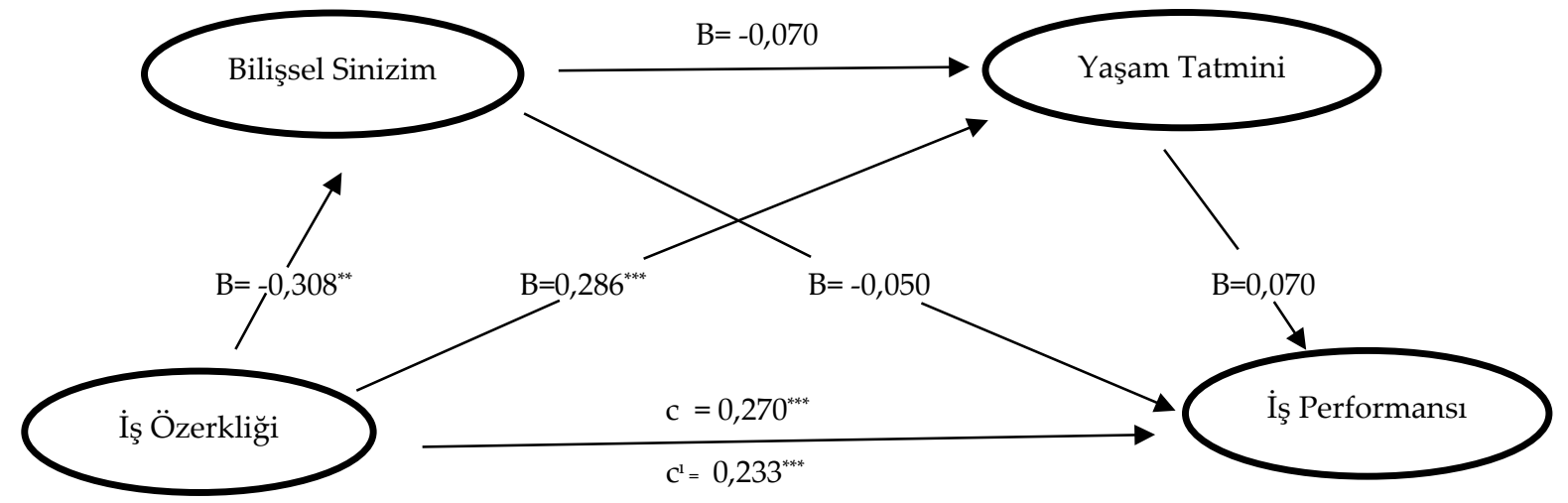

Şekil 2. Model 1 seri çoklu aracıllk sonuçları, ${ }^{*} \mathrm{p}<.05,{ }^{* *} \mathrm{p}<.01,{ }^{* * *} \mathrm{p}<.001$

Sağlık çalışanlarının iş özerkliğinin iş performansı üzerindeki toplam etkisi (c yolu) (B: 0,270, SE=0,056 \%95 CI $[0,160,0,380], t: 4,862, p=0,000)$ pozitif yönde anlamlı düzeydedir. Sağllk çalışanlarının iş özerkliğinin, bilişsel sinizm düzeyleri üzerinde negatif yönde ve istatistiksel olarak anlamlı etkisi bulunmaktadır (B: -0,308, $\mathrm{SE}=0,0941 \% 95$ CI $[-0,494,-0,122], \mathrm{t}:-3,273, \mathrm{p}=0,001)$.

Sağlık çalışanlarının iş özerkliğinin yaşam tatmini üzerinde istatistiksel olarak pozitif yönlü anlamlı bir etkisi (B:0,286, SE=0,069, \%95 CI [0,149, 0,422], t:4,123 p=0,000) olduğu sonucuna ulaşılmıştır. Birinci aracı değişken olan bilişsel sinizmin ikinci aracı değişken olan yaşam tatmini üzerinde istatistiksel olarak anlamlı bir etkisi (B:-0,070, SE=0,058, \%95 CI [-0,270, 0,041], t: -1,216 p=0,226) olmadığ sonucuna ulaşılmıştır. Aynı şekilde sağlık çalışanlarının bilişsel sinizm düzeylerinin iş performansı üzerindeki doğrudan etkisinin istatistiksel olarak anlamlı (B:-0,050, SE=0,048, \%95 CI [-0,145, 0,046], t: -1,027 p=0,306) olmadığ1 sonucuna ulaşılmıştır. Sonuçların istatistiksel olarak anlamlı olmamasının nedeni, hem p değerlerinin 0,001 'den yüksek çıkması hem de güven aralıklarının içerisinde sıfır içermesinden kaynaklanmaktadır.

İkinci aracı değişken olan yaşam tatmininin iş performansı üzerindeki doğrudan etkisinin istatistiksel olarak anlamlı (B:0,070, SE=0,068, \%95 CI [-0,064, 0,204], t: 1,030 p=0,305) olmadığ1 sonucuna ulaşılmıştır. Bunun nedeni, güven aralıkları içerisinde sıfır olması ve p değerinin 0,001 'den yüksek çıkmış olmasındandır. İş özerkliği ve diğer tüm aracı değişkenler aynı anda denkleme girildiğinde, iş özerkliğinin iş performansına doğrudan etkisi ( $\mathrm{C}^{1}$ yolu) istatistiksel olarak anlamlı olduğu tespit edilmiştir (B: 0,233, SE=0,061, \%95 CI [0,114, $0,353], \mathrm{t}: 3,852, \mathrm{p}=0,000)$. İş özerkliği, örgütsel sinizm ve yaşam tatmininin iş performansındaki değişimin yaklaşık \%14'nü açıklamaktadır ( $F=8,682, \mathrm{R}^{2}=0,149$, Sig.= 0,000).

Model 1'deki dolaylı yolların anlamlı olup olmadığına yönelik gerçekleştirilen analiz sonucundaki bootstrap katsayı ile \%95 güven aralıkları alt ve üst limitleri Tablo 2'de yer almaktadır. Tablodan da görüldüğü gibi, 
toplam etki değeri 0,270, doğrudan etki değeri 0,233, toplam dolaylı etki değeri 0,037 olduğu saptanmıştır. Modelde üç dolaylı etki bulunmaktadır. Birinci dolaylı etkide; iş özerkliği (X) bilişsel sinizm (M1) aracılığıyla iş performansı (Y) üzerinde anlamlı etkisinin olmadığı (bootstrap $=0.015, \% 95 \mathrm{CI}=-0,012,0,048$ ), ikinci dolaylı etkide iş özerkliği yaşam tatmini (M2) aracılı̆̆ıyla iş performansını anlamlı olarak etkilemediği (bootstrap = $0,020, \% 95 \mathrm{CI}=-0,025,0,063$ ) ve üçüncü dolaylı etki iş özerkliğinin bilişsel sinizm ve yaşam tatmini aracıllı̆̆ıla iş performansını anlamlı olarak etkilemediği (bootstrap $=0,002, \% 95 \mathrm{CI}=-0,003,0,007$ ) tespit edilmiştir. $\mathrm{Bu}$ durum, güven aralıklarının içerisinde sıfır olmasından kaynaklamaktadır. Dolayısıyla, iş özerkliğinin iş performansını etkilemede bilişsel sinizm ve yaşam tatmininin seri çoklu aracılık etkisi bulunmamaktadır.

Tablo 2. Model 1 Seri-Çoklu Aracı Etkiye Ait Broostrapt Sonuçları

\begin{tabular}{|c|c|c|c|c|}
\hline \multicolumn{5}{|l|}{ Model 1} \\
\hline & & & \multicolumn{2}{|c|}{ \%95 Güven Aralıkları } \\
\hline Etki & Boostrapt Katsayısı & Standart Hata & Alt Limit & Üst Limit \\
\hline Toplam Etki & 0,270 & 0,056 & 0,160 & 0,380 \\
\hline Doğrudan Etki (c1 yolu) & 0,233 & 0,061 & 0,114 & 0,353 \\
\hline Toplam Dolaylı Etki & 0,037 & 0,025 & $-0,013$ & 0,085 \\
\hline Dolaylı Etki (İÖ $\rightarrow$ BS $\rightarrow$ İP $)$ & 0,015 & 0,015 & $-0,012$ & 0,048 \\
\hline Dolaylı Etki (ïÖ $\rightarrow$ YT $\rightarrow$ İP) & 0,020 & 0,022 & $-0,025$ & 0,063 \\
\hline Dolaylı Etki $(\dot{\mathrm{I} O ̈} \rightarrow \mathrm{BS} \rightarrow \mathrm{YT} \rightarrow \mathrm{I} \mathrm{P})$ & 0,002 & 0,002 & $-0,003$ & 0,007 \\
\hline
\end{tabular}

Not: İş özerkliği= İÖ, İş Performansı=IP, Bilişsel Sinizm=BS, Yaşam Tatmini=YT

İş özerkliğinin iş performansı üzerindeki etkisinde, duyuşsal sinizmin ve yaşam tatmininin seri-çoklu aracılık rolünü belirlemek için kullanılan bootstrap tekniği sonucunda elde edilen bulgular Şekil 3'de sunulmuştur (Hayes, 2013).

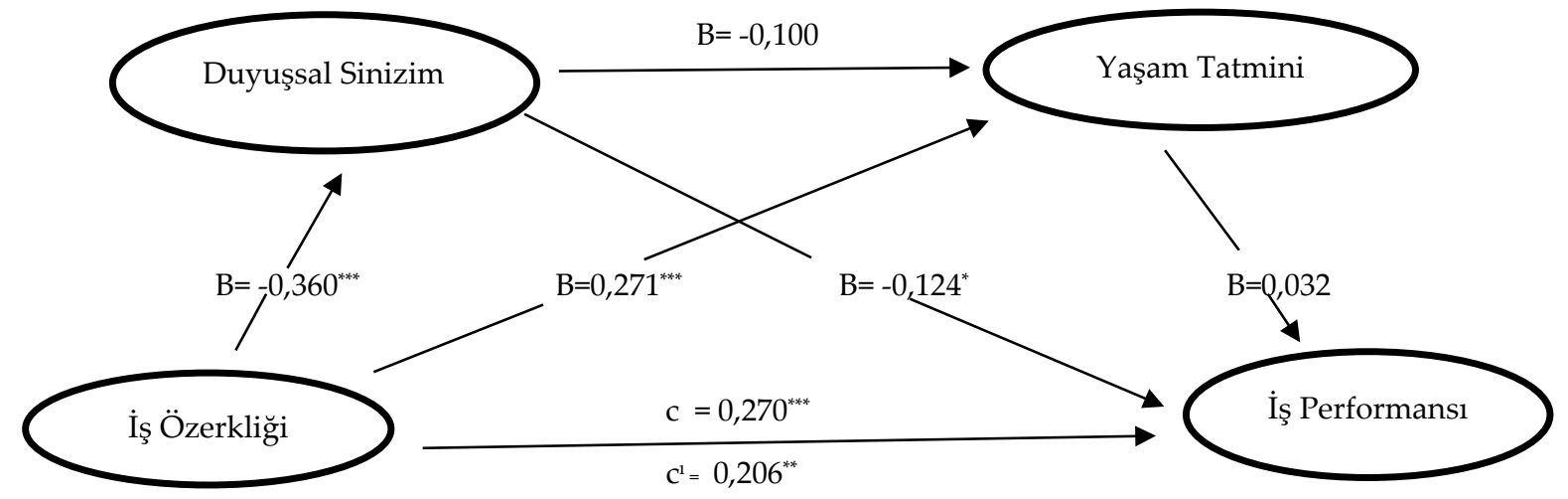

Şekil 3. Model 2 Seri çoklu aracılık sonuçları, ${ }^{*} \mathrm{p}<.05,{ }^{* *} \mathrm{p}<.01,{ }^{* * *} \mathrm{p}<.001$

Sağlık çalışanlarının iş özerkliğinin iş performansı üzerindeki toplam etkisi (c yolu) (B: 0,270, SE=0,056 \%95 CI $[0,160,0,380], t: 4,862, p=0,000)$ pozitif yönde anlamlı düzeydedir. Sağlık çalışanlarının iş özerkliği, duyuşsal sinizm düzeylerini negatif yönde ve istatistiksel olarak anlamlı bir şekilde etkilemektedir (B: -0,360, SE=0,073 $\% 95$ CI [-0,505, -0,215], t: $-4,9133, \mathrm{p}=0,000)$.

Sağlık çalışanlarının iş özerkliğinin yaşam tatmini üzerinde istatistiksel olarak pozitif yönlü anlamlı bir etkisi olduğu sonucuna ulaşılmıştır (B:0,271, SE=0,072, \%95 CI [0,129, 0,413], t:3,768 p=0,000). Güven aralıklarının içerisinde sıfır olması ve $p$ değerinin 0,001 'den yüksek çıkması nedeniyle, duyuşsal sinizmin yaşam tatmini üzerinde istatistiki olarak anlamlı bir etkisinin olmadığı saptanmıştır (B:-0,100, SE=0,074, \%95 CI [-0,246, 0,047], $\mathrm{t}:-1,344 \mathrm{p}=0,181)$.

Güven aralıklarının içerisinde sıfır olmaması ve p değerinin 0,05'den düşük çıkması nedeniyle, birinci aracı değişken olan duyuşsal sinizm düzeylerinin iş performansı üzerindeki doğrudan etkisi istatistiksel olarak anlamlı (B:-0,124, SE=0,061, \%95 CI [-0,246, -0,003], t: -2,026 p=0,045) olduğu tespit edilmiştir. Diğer taraftan, ikinci aracı değişken olan yaşam tatmininin iş performansı üzerindeki doğrudan etkisinin istatistiksel olarak anlamlı (B:0,032, SE=0,067, \%95 CI [-0,071, 0,194], t: 0,921 p=0,359) olmadığı sonucuna ulaşılmıştır. Çıkan sonucun anlamlı olmamasının nedeni, güven aralıkları içerisinde sıfır içermesi ve p değerinin 0,001 'de yüksek çıkmasıdır. İş özerkliği ve diğer tüm aracı değişkenler aynı anda denkleme girildiğinde, iş özerkliğinin iş 
performansına doğrudan etkisi ( $\mathrm{C}^{1}$ yolu) istatistiksel olarak anlamlı olduğu tespit edilmiştir (B: 0,206, $\mathrm{SE}=0,062$, \%95 CI [0,084, 0,329], t: 3,334, p=0,001). İş özerkliği, örgütsel sinizm ve yaşam tatmininin iş performansındaki değişimin yaklaşık \%16'sını açılamaktadır ( $F=9,868, R^{2}=0,166$, Sig.= 0,000).

Model 2'deki dolaylı yolların anlamlı olup olmadığına yönelik gerçekleştirilen analiz sonucundaki bootstrap katsayı ile \%95 güven aralıkları alt ve üst limitleri Tablo 3'de yer almaktadır. Tablodan da görüldüğü gibi, toplam etki değeri 0,270, doğrudan etki değeri 0,206, toplam dolaylı etki değeri 0,064 olduğu saptanmıştır. Modelde üç dolaylı etki bulunmaktadır. Birinci dolaylı etkide; iş özerkliğinin $(X)$ iş performansı $(Y)$ üzerine etkisinde duyuşsal sinizmin (M1) aracı etkisinin anlamlı olmadığ 1 (bootstrap $=0.045, \% 95 \mathrm{CI}=-0,011,0,109$ ), ikinci dolaylı etkide iş özerkliğinin iş performansı üzerindeki etkisinde yaşam tatmininin (M2) aracılık etkisinin anlamlı olmadığ (bootstrap $=0,017, \% 95 \mathrm{CI}=-0,025,0,058$ ) ve üçüncü dolaylı etkide iş özerkliğinin duyuşsal sinizm ve yaşam tatmini aracıllı̆ıyla iş performansını anlamlı olarak etkilemediği (bootstrap=0,002, $\% 95 \mathrm{CI}=-0,004,0,012$ ) saptanmıştır. Bunun nedeni, güven aralıklarının içerisinde sıfır olmasından kaynaklanmaktadır. Üçüncü dolaylı etkinin sonucuna göre, iş özerkliğinin iş performansı üzerindeki etkisinde duyuşsal sinizm ve yaşam tatmininin seri çoklu aracıllk etkisi bulunmamaktadır.

Tablo 3. Model 2 Seri-Çoklu Aracı Etkiye Ait Broostrapt Sonuçları

\begin{tabular}{|c|c|c|c|c|}
\hline \multicolumn{5}{|l|}{ Model 2} \\
\hline & & & \multicolumn{2}{|c|}{ \%95 Güven Aralıkları } \\
\hline Etki & Boostrapt Katsayısı & Standart Hata & Alt Limit & Üst Limit \\
\hline Toplam Etki (c yolu) & 0,270 & 0,056 & 0,160 & 0,380 \\
\hline Doğrudan Etki ( ${ }^{1}$ yolu) & 0,206 & 0,062 & 0,084 & 0,329 \\
\hline Toplam Dolaylı Etki & 0,064 & 0,036 & $-0,003$ & 0,138 \\
\hline Dolaylı Etki (İ̈ $\rightarrow$ DUYS $\rightarrow$ İP) & 0,045 & 0,030 & $-0,011$ & 0,109 \\
\hline Dolaylı Etki (ïÖ $\rightarrow$ YT $\rightarrow$ İP) & 0,017 & 0,020 & $-0,025$ & 0,058 \\
\hline $\begin{array}{l}\text { Dolayli } \quad \text { Etki } \\
\text { DUYS } \rightarrow \text { YT } \rightarrow \text { İP) }\end{array} \quad$ IÖ $\quad \rightarrow$ & 0,002 & 0,004 & $-0,004$ & 0,012 \\
\hline
\end{tabular}

Not: İş özerkliği= İÖ, İş Performansı=İP, Duyuşsal Sinizim=DUYS, Yaşam Tatmini=YT

Analiz sonuçlarına göre, H1a, H1b, H1c, H1f ve H1k hipotezleri kabul edilmiş, H1e, H1h, H11, H11, H1m, H1n, H1o, H1p ve H1r hipotezleri ise red edilmiştir.

\section{SONUÇ ve TARTIŞMA}

Sağlık çalışanlarına yönelik yapılan bu çalışmada, çalışanların iş özerkliğinin iş performansına etkisinde örgütsel sinizm ve yaşam tatminini seri-çoklu aracı etkisi test edilmiştir.

Yapılan analizler sonucunda, sağlık çalışanlarının iş özerkliği, iş performansı ve yaşam tatmini düzeylerinin ortalamanın üzerinde değerler aldığı saptanmıştır. İş performansının dördün üzerinde değer alması, sağlık çalışanlarının performans algılarının yüksek olduğunu göstermektedir. Çıkan bu sonuçlara göre, araştırmaya konu olan sağlık kuruluşlarında çalışan bireylerin işyerlerinde özerk olmaları, performans algılarının ve iş dışında tatmin düzeylerinin yüksek olması, verilen sağlık hizmetinin kalitesi, hasta memnuniyetinin ve hastanenin performans artışı açısından oldukça önemlidir. Mevcut çalışma, literatürde sağlık çalışanlarına yönelik olarak yapılan çalışmalar ile tutarlılık göstermektedir. Kutaniş (2018: 86) tarafından yapılan çalışmada iş özerkliğinin ortalama değeri 4,36; Şantaş vd., (2016: 879) tarafından yapılan çalışmada iş performansının ortalama değeri 3,74 olduğu saptanmıştır. Norveç'li doktorlar üzerine 1994-2002 yılları arasında yapılan bir çalışmada, yaşam memnuniyetinin 1994 yılında 5,21 iken 2002 yılında 5,32'ye yükseldiği tespit edilmiştir (1=memnun değil, 7=çok memnun). Ayrıca Norveç'li doktorların yarısının yaşam memnuniyetlerini çok yüksek (6 ile 7 arası) olduğu saptanmıştır (Nylenna vd., 2005: 5).

Araştırma sonucunda, sağlık çalışanlarının örgütsel sinizim boyutlarının (bilişsel, duyuşsal ve davranışsal boyutlar) düzeyleri ortalamanın altında değer aldığı tespit edilmiştir. Örgütsel sinizm, çalışanların çalıştıkları işyerine karşı olumsuz tutum içerisinde olmasını ifade etmekte olup, sağlık kurumlarında sinik çalışanların olması işlerin aksamasına, hizmetin kalitesinin düşmesine ve hasta bakımının olumsuz olarak etkilenmesine neden olabilmektedir. Bu nedenle, çalışanlarda örgütsel sinizm düzeylerinin düşük düzeyde olması tercih edilmektedir. Sağlık çalışanlarına yönelik yapılan çalışmaların sonuçlarına göre örgütsel sinizm boyutlarının (genel sinizm, bilişsel, duyuşsal ve davranışsal boyut) ortalama değerleri; İçerli ve Yıldırım (2012: 171) 
tarafından bilişsel sinizm 2,72, davranışsal sinizm 2,72 ve duyuşsal sinizm 2,58; Köroğlu ve Yardan (2016: 16) tarafından genel sinizm 2,60, bilişsel boyut 2,49, duyuşsal boyut 2,64 ve davranışsal boyut 2,66; Şantaş vd. (2016: 879) tarafından genel sinizm 2,82; Tutar ve Köse (2018: 164) tarafından genel sinizm 2,88 olarak saptanmıştır. Literatürdeki çalışmalarda da çalışanların örgütsel sinizm ve boyutlarının ortalama değerin altında olduğu saptanmıştır. Dolayısıyla, araştırmadan çıkan sonuçlar, sağlık sektöründe çalışanlar üzerine daha önce yapılmış olan çalışmalar ile örtüşmektedir. Bu araştırmada sağlık çalışanlarının örgütsel sinizm düzeylerinin düşük olduğu tespit edilmiş olsa da, sağlık kurumları tarafından çalışanların örgütsel sinizm düzeylerinin daha da azaltılması gerekmektedir. Bunun için, sağlık kurumlarında ki yöneticiler tarafından örgütsel sinizme neden olan faktörlerin neler olduğu saptanmalı ve bu faktörlerin ortadan kaldırılması için gerekli önlemlerin alınması gerekmektedir.

Araştırmada, sağlık çalışanlarının işlerinde özerk olmaları durumunda daha iyi performans gösterdikleri saptanmıştır. Çıkan bu sonuç farklı sektörlerde yapılan çalışmalarla benzerlik göstermektedir. Üniversite öğrencilerine (Saragih 2011: 210), imalat sanayi çalışanlarına (Çekmecelioğlu ve Günsel, 2011: 893), doktor ve hemşirelere (Khan vd., 2012: 2703) ve belediye çalışanlarına (Kuvaas vd.,: 16) yönelik yapılan çalışmalarda kurumlar tarafından çalışanlara ne kadar çok iş özerkliği sağlanırsa, o kadar fazla iş performansının arttığı tespit edilmiştir. Diğer taraftan, Norveç'te hizmet sektöründe çalışan bireylere yönelik yapılan çalışmada ise, iş özerkliğinin iş performansı üzerinde herhangi bir etkisi bulunamamıştır (Dysvik ve Kuvaas, 2011: 15).

Mevcut araştırmanın diğer bir sonucuna göre, çalışanların iş özerkliğinin örgütsel sinizm boyutları (bilişsel ve duyuşsal sinizm boyutları) üzerinde olumsuz etkisinin olduğu saptanmıştır. Dolayısıyla, sağlık çalışanlarına işyerinde özerklik tanınması, örgütsel sinizm gibi olumsuz davranışların sergilenmesini engellemektedir. Literatürdeki çalışmalarda da çalışanların iş özerkliği örgütsel sinizm düzeylerini negatif yönde etkilediği tespit edilmiştir. Çiçek vd. (2018: 32) sağlık çalışanına yönelik yaptıkları çalışmada, işyerindeki özerkliğin artması örgütsel sinizmi azaltığı sonucuna ulaşmışlardır. Shaharruddin ve Ahmad (2015: 95) çalışmalarında, Malezya göçmenlik bürosunda çalışan bireylerin yaptıkları işlerde özerk olmaları, çalışanların sinik davranışlar göstermediğini saptamışlardır. Tunç (2018: 72), hastane çalışanlarına yönelik yaptığı çalışmasında örgütsel vatandaşlık davranışının duygusal zekâyı pozitif yönde; iş özerkliğinin örgüt güvenlik iklimi ve duygusal zekâyı pozitif yönde; örgüt güvenlik iklimi ve duygusal zekâ değişkenlerinin örgütsel sinizmi negatif yönde etkilediğini tespit etmiştir. Ancak, iş özerkliğinin örgütsel sinizme etki etmediği sonucuna ulaşmıştır.

Araştırmada, çalışanların duyuşsal sinizm düzeylerinin artması iş performanslarının düşmesine neden olduğu saptanmıştır. Dolayısıyla, sağlık çalışanlarının işyerlerine ve çalışma arkadaşlarına karşı olumsuz duygular içerisinde olmaları, çalışanların performanslarının düşmesine neden olabilecektir. Diğer taraftan araştırmada sağlık çalışanlarının bilişsel sinizm düzeyleri iş performanslarına etki etmediği tespit edilmiştir. Yani, çalışanların işyerleri ve çalışma arkadaşları ile ilgili olumsuz inançlar içerisinde olmaları, onların iş performanslarını etkilemediği düşünülebilir. Kahya'nın (2013: 42) yaptığı çalışmada ise, örgütsel sinizmin duyuşsal boyutu iş performansını negatif yönde etkilediği, sinizmin diğer boyutlarının ise iş performansı üzerinde herhangi bir etkisinin olmadığı tespit edilmiştir. Yapılan bu çalışma mevcut araştırmayı destekler niteliktedir. Başka bir çalışmada da, örgütsel sinizmin tüm boyutlarının iş performansı üzerinde herhangi bir etkisinin olmadığı saptanmıştır (Çakıcı ve Doğan, 2014: 87). Literatürde var olan diğer çalışmalarda ise çalışanların yaşadığı sinizmin tüm boyutları (duyuşsal, bilişsel ve davranışsal boyutlar) iş performanslarını negatif yönde etkilediği tespit edilmiştir (Akdemir vd., 2016: 128; Bacaksız vd., 2018, 55; Uysal ve Yıldız, 2014: 846).

Çalışanların, yaşamlarının büyük bir bölümünün işyerinde geçirdiği düşünülecek olursa, işinden ya da işyerinden kaynaklanan olumsuzluklar çalışanların sinik davranışlar sergilemesine neden olabilir. Sinik davranışlar sergileyen çalışanlarda hem iş tatminlerinde hem de yaşam tatminlerinde düşüş yaşanabilir (Çivilidağ, 2015: 279). Ancak, araştırmanın sonucuna göre, sağlık kurumlarında çalışan bireylerin bilişsel sinizm ve duyuşsal sinizm düzeyleri sağlık çalışanlarının iş dışında ki tatmin düzeylerini etkilemediği tespit edilmiştir. Buna göre, çalışanların iş ve iş yeri ile ilgili yaşadığı sinizm, yaşam tatminlerini olumlu ya da olumsuz olarak etki etmektedir. Mevcut araştırmada çıkan bu sonucun aksine, yapılan başka çalışmalarda çalışanların sinizm düzeyleri yaşam tatminlerini olumsuz yönde etkilediği yönündedir. Yani sinizm yaşayan çalışanlar, iş dışında tatmin düzeyleri düşmektedir. Aslan ve Yılmaz (2013: 590), ilkokul öğretmenine yönelik yaptıkları çalışmada sinizmin bilişsel ve duyuşsal boyutları ile öğretmenlerin yaşam tatmini arasında negatif 
yönlü ilişki olduğunu saptamışlardır. Çivilidağ (2015: 279) yaptığı çalışmada üniversitede çalışan öğretim elemanlarının örgütsel sinizm, işe yabancılaşma ve yaşam tatmini arasındaki ilişkiyi incelemiştir. İşe yabancılaşma ve örgütsel sinizmin yaşam tatmini üzerinde negatif etkisinin olduğu sonucuna ulaşmıştır. Kasalak (2019) yaptığı çalışmada öğrenci sinizmi ile öğrencilerin yaşam tatminleri arasındaki ilişkiyi incelemeyi amaçlamıştır. Kız öğrencilerin erkek öğrencilere göre daha fazla sinizme sahip oldukları ve yaşam tatminlerinin daha az olduğu sonucuna ulaşmıştır. Örgütsel sinizm ve alt boyutlarının yaşam tatminini olumsuz olarak etkilediğini tespit etmiştir. Literatürdeki diğer çalışmalarda da örgütsel sinizmin yaşam tatmini üzerinde olumsuz etkisi olduğu sonucuna ulaşılmıştır (Cazan ve Năstasă, 2015: 1577; Mehdinezhad, 2015: 259).

Araştırmada, sağlık çalışanlarının işyerinde özerk olması, yaşam tatminlerini arttırdığı sonucuna ulaşılmıştır. Coad ve Binder (2014) yaptıkları çalışmada iş özerkliğinin hem iş tatminini hem de yaşam tatminini olumlu yönde etkilediğini tespit etmişlerdir (Coad ve Binder, 2014: 8). Dolayısıyla, Coad ve Binder tarafından yapılan çalışma mevcut çalışmayı destekler niteliktedir.

Bireylerin, hayata pozitif bakabilmeleri için belli bir yaşam doyumuna ulaşmaları gerekmektedir. Ancak, bireyler iş dışında yaşadıkları travmatik olaylar ve iş içerisinde yaşadıkları bir takım olumsuzluklar nedeniyle, yaşam tatminlerinde düşme yaşayabilirler. Yaşam tatminine ulaşamayan çalışanlar günlük yaşantıları içerisinde mutsuz olmakta, kendilerini huzursuz hissetmekte ve konsantrasyon sorunları yaşamaktadırlar. Böylece, işte sergiledikleri performans olumsuz olarak etkilenebilmektedir (Uludağ, 2019: 293). Dolayısıyla, çalışanların yaşam tatmin düzeylerinin yüksek olması, onların işyerindeki performanslarının da yükselmesine neden olmaktadır. Ancak, mevcut araştırmadan çıkan sonuca göre, sağlık çalışanlarının yaşam taminlerinin iş performansları üzerinde herhangi bir etkisinin olmadığı saptanmıştır. Oysa ki literatürde yapılan çalışmalarda yaşam tatmininin iş performansına olumlu yönde etki ettiği yönündedir (Çınar ve Özyılmaz, 2018: 143; Jones, 2006: 33; Kale, 2015: 114; Özy1lmaz, 2018: 64).

Model 1'in ilk aracıllk sonucuna göre, iş özerkliğinin iş performansına etkisinde, örgütsel sinizmin bilişsel boyutunun aracı rolünün olmadığı tespit edilmiştir. Dolayısıyla, iş özerkliği, iş performansına bilişsel sinizm aracılığı ile etki etmemektedir. Yani, sağlık çalışanları sinik tutmlara sahip olsalar bile onların iş performanslarını etkilemediği, iş performans düzeyleri doğrudan iş özerkliğine bağlı olduğu söylenebilir. Model 1'in ikinci aracılık sonucuna göre, sağlık çalışanlarının iş özerkliğinin iş performansına etkisinde yaşam tatmininin aracı etkisinin olmadığı saptanmıştır. Dolayısıyla, sağlık çalışanlarının iş dışında ki tatmin duygularının yüksek ya da düşük olması işte gösterdikleri performanslarını etkilemediği, performanslarının düşük ya da yüksek olması işlerinde özerk olmalarına bağlı olduğu söylenebilir. Model 1'in seri-çoklu aracılık sonucuna göre, iş özerkliğinin iş performansına etkisinde bilişsel sinizmin ve yaşam tatmininin seri-çoklu aracılık etkisinin olmadığı sonucuna ulaşılmıştır. Yani, örgütsel sinizm ve yaşam tatmininin aynı anda aracılıkları olmadan iş özerkliği iş performansına doğrudan etki etmektedir.

Model 2'nin ilk aracılık sonucuna göre, çalışanların iş özerkliğinin iş performansına etkisinde, örgütsel sinizmin duyuşsal boyutunun aracılı̆̆ında olmadığı; ikinci aracılık sonucuna göre, çalışanlarının iş özerkliğinin iş performansına etkisinde yaşam tatmininin aracılığında olmadığı ve üçüncü aracılık sonucuna göre, çalışanların iş özerkliğinin iş performansına etkisinde duyuşsal boyutun ve yaşam tatmininin seri-çoklu aracılığında olmadığı saptanmıştır. Bu sonuçlara göre, araştırmaya katılan çalışanların iş özerkliğinin iş performansına üzerinde etkisi duyuşsal boyut ve yaşam tatmininin aracıllğı olmadan gerçekleşmektedir.

Araştırmanın aracılık analiz sonuçlarına göre, hastane yönetimi tarafından sağlık çalışanlarına ne kadar özerklik tanınırsa, o kadar yüksek performans göstereceklerdir. Sağlik kuruluşlarında doktorundan güvenlik görevlisine kadar her çalışanın performanslarının yüksek olması durumunda hastalar ile daha iyi ilgilenebilir ve hasta memnuniyeti daha iyi sağlanabilir. Böylece, sağlık çalışanlarının performansının artması sağlık kurumlarının da performansının artmasına neden olabilecektir. Bunun için, sağlık çalışanlarına belirli düzeylere kadar iş özerkliği sağlanmalıdır.

Literatür taramasında iş özerkliliği ve yaşam tatminine ilişkin çalışmaların az olması, iş özerkliğinin iş performansına etkisinde örgütsel sinizm ve yaşam tatmininin seri-çoklu aracılık etkisini araştıran çalışmaya rastlanmamış olması alanda bir eksiklik olduğunu göstermektedir. Bu çalışma, alandaki boşluğu doldurması açısından önemlidir. Ayrıca, iş özerkliği, iş performansı, örgütsel sinizm ve yaşam tatmininin sağlık 
kuruluşlarındaki öneminin ve sonuçlarının alana katkı sağlayacağı düşünülmektedir. İleride yapılacak benzer çalışmalara yol göstereceği düşünülmektedir.

Araştırmanın, sadece bir ilde yapılmış olması ve özel hastanelere yönelik yapılmış olması önemli kısıtıdır. İleri ki çalışmalarda, Trakya bölgesinde diğer iki ilde faaliyet gösteren özel hastane çalışanları araştırmaya dahil edilmelidir. Ayrıca, özel ve kamu hastane çalışanları karşılaştırma yapılmalıdır. Araştırmanın diğer bir kısıtı ise, sözkonusu dört değişken (iş özerkliği, iş performansı, örgütsel sinizm ve yaşam tatmini) ile seri-çoklu aracılık etkisinin araştırılmış olmasıdır. İleriki çalışmalarda, mevcut çalışmaya konu olan değişkenler ile örgütsel bağlllık, iş tatmini, işten ayrılma niyeti, stres gibi değişkenler ilişkilendirilmeli, hem aracı hem de durumsal etki düzeyleri incelenmelidir. Ayrıca, değişkenler ile demografik faktörler arasındaki durumsal etki düzeyleri incelenmelidir.

\section{KAYNAKLAR}

Ağca, V., Kurt, M. (2007). İç Girişimcilik ve Temel Belirleyicileri: Kavramsal Bir Çerçeve. Erciyes Üniversitesi İktisadi ve İdari Bilimler Fakültesi Dergisi, 29, 83-112.

Akdemir, B., Kırmızıgül, B., Zengin, Y. (2016). Örgütsel Sinizm İle İş Performansı Arasındaki İlişki ve Bir Araştırma. Kahramanmaraş Sütçü İmam Üniversitesi İ.I.B.F. Dergisi, 6 (2), 115-130.

Akdemir, B., Duman, Ç. M. (2016). Duygusal Bağlılık Ve İşgören Performansı Arasındaki İlişkiye Yönelik Bir Araştırma. International Journal of Social Science, 46, 343-357.

Akgündüz, Y . (2013). Konaklama İşletmelerinde İş Doyumu, Yaşam Doyumu ve Öz Yeterlilik Arasındaki İlişkinin Analizi. Celal Bayar Üniversitesi Sosyal Bilimler Dergisi , 11 (1) , 180-204 .

Akyüz, B., Eşitti, B. (2015). Hizmet İşletmelerinde Örgütsel Bağlılığın İş Performansı ve İşten Ayrılma Niyeti Üzerindeki Etkisi: Çanakkale Örnekleminde Bir Araştırma. Bartın Üniversitesi I..̇.B.F. Dergisi, 6(11), 2339.

Armağan, A. (2013). Girişimcilik Ve Otonomi (Özerklik) İlişkisi: Ege Üniversitesi İletişim Fakültesi Öğrencileri Üzerinde Bir Araştırma. Turkish Studies, 8 (12), 49-69.

Altınöz, M., Çöp, S , Sığındı, T. (2011). Algılanan Örgütsel Bağlılık Ve Örgütsel Sinizm İlişkisi: Ankara'daki Dört Ve Beş Yıldızlı Konaklama İşletmeleri Üzerine Bir Araştırma. SÜ İ̈BF Sosyal Ekonomik Araştırmalar Dergisi, 11 (21), 285-316.

Aslan, H., Yilmaz, E. (2013). The Study Of Teachers' General Cynicism Inclinations In Terms Of Life Satisfaction And Other Variables. Creative Education, 4(9), 588-591.

Bacaksiz, E. F., Tuna, R., Seren, K. H. A. (2018). The Effects of Organizational Identification and Organizational Cynicism on Employee Performance Among Nurses. International Journal of Caring Sciences, 11(3), 1707-1714.

Bahar, B. (2019). Sosyal Öğrenme Kuramı ve Sosyal Değişim Kuramı Perspektifinden Etik Liderlik, Balkan Sosyal Bilimler Dergisi, 8 (16) 237-242.

Begenirbaş, M., Turgut, E. (2014). İş Performansının Sağlanmasında Çalışanın Duygusal Emeğinin ve Örgütte Güven Algisının Etkileri. "İ̧̧, GüÇ" Endüstri İlişkileri ve İnsan Kaynakları Dergisi, 16 (3), 131-149.

Brandes, P., Das, D. (2015). Locating Behavioral Cynicism at Work: Construct Issues and Performance Implications. In Employee Health, Coping and Methodologies. 233-266.

Bozgül, N. (2018). Stratejik Çeviklik, İş Özerkliği, Örgütsel İletişim, Örgüt Güvenlik İklimi, Örgütsel Bağhllk Arasındaki İlişkiler Ve Sağglk Sektöründe Bir Araştırma. (Yayımlanmamış yüksek lisans tezi). İstanbul Arel Üniversitesi/Sosyal Bilimler Enstitüsü, İstanbul.

Cazan, A. M., Năstasă, L. E. (2015). Emotional Intelligence, Satisfaction With Life And Burnout Among University Students. Procedia-Social and Behavioral Sciences, 180, 1574-1578. https://doi.org/10.1016/j.sbspro.

Coad, A., Binder, M. (2014). Causal Linkages Between Work And Life Satisfaction And Their Determinants İn A Structural VAR Approach, The Levy Economics Institute Working Paper, 809, 1-16. 
Çakıcı, A., Doğan, S. (2014). Örgütsel Sinizmin İş Performansına Etkisi: Meslek Yüksekokullarında Bir Araştırma. Doğuş Üniversitesi Dergisi, 15(1), 79-89.

Çekmecelioğlu, H. G., Günsel, A. (2011). Promoting Creativity Among Employees Of Mature İndustries: The Effects Of Autonomy And Role Stress On Creative Behaviors And Job Performance. Procedia-Social and Behavioral Sciences, 24, 889-895.

Çınar, Ö., Özyılmaz, F. Z. (2018). Duygusal Zekâ, Yaşam Tatmini Ve İş Performansı Arasındaki İlişkilerin İncelenmesi: Ağrı İbrahim Çeçenve Bayburt Üniversitelerinde Çalışan Akademisyenler Üzerinde Bir Uygulama, Dicle Üniversitesi İktisadi Ve İdari Bilimler Fakültesi Dergisi, 8 (16), 131-149.

Çınar, Ö., Özyılmaz, F. Z. (2019). İş Tatmini İle Yaşam Tatmini Arasındaki İlişki: Bayburt Üniversitesinde Bir Uygulama. Iğdır Üniv. Sos. Bil. Dergisi, (17), 533-556.

Çiçek, S. (2018). İş Özerkliği, Kariyer, Sinizm, Performans Ve Akıllı Sadelik Arasındaki İlişkiler Ve Bir Araştırma. (Yayımlanmamış yüksek lisans tezi). İstanbul Arel Üniversitesi/Sosyal Bilimler Enstitüsü, İstanbul.

Çiçek, S., Yıldırım, O., Sezginer, B. (2018). Relationship Between Work Autonomy, Career, Cynicism, Performance, Smart Simplicity and a Research, International Journal of Management and Applied Science (IJMAS), 4(5), 27-33.

Çinko, L., Utaş, T. (2017). Hibrit İş Özellikleri Çerçevesinde Mavi Yakali Çalişanlarin İş Motivasyonu Ve İsrafin Önlenerek Kaynaklarin Verimli Kullanilmasi. İstanbul Üniversitesi İktisat Fakültesi Mecmuası, 67 (1), 4356.

Çivilidağ, A. (2015). Öğretim Elemanlarında Örgütsel Sinizm Ve İşe Yabancılaşma Arasındaki İlişkide Yaşam Doyumunun Aracı Rolü. İş, Güç, Endüstri İlişkileri ve İnsan Kaynakları Dergisi, 17 (4), 259-286.

Çolak, İ., Altınkurt, Y., Yılmaz, K. (2017). Öğretmenlerin Özerklik Davranışları ile İş Doyumları Arasındaki İlişki, KSBD, 9(2), 189-208.

Çotul A., Altındağ E. (2018). İşletme Etiğinde Sinizm ve İşgören Performansı Arasındaki İlişki: Tekstil Sektöründe Çalışanlara Yönelik Bir Uygulama, BMIJ, 6(4), 1198-1214.

Dağlı, A., Baysal, N. (2016). Yaşam Doyumu Ölçeğinin Türkçe’ye Uyarlanması: Geçerlik Ve Güvenirlik Çalışması, Elektronik Sosyal Bilimler Dergisi, 15(59), 1250-1262.

De Cuyper, N., De Witte, H. (2006). Autonomy And Workload Among Temporary Workers: Their Effects On Job Satisfaction, Organizational Commitment, Life Satisfaction And Self-Rated Performance. International Journal of Stress Management, 13, 441-459.

Dean, J. W., Brandes, P., Dharwadkar, R. (1998). Organizational Cynicism, Academy of Management Review, 23(2), 341-352.

Durrah, O., Chaudhary, M., Gharib, M. (2019). Organizational Cynicism and Its Impact on Organizational Pride in Industrial Organizations. International Journal Of Environmental Research And Public Health, 16(7), 1-16.

Doğan, H., Can, A. (2009). Örgütlerde Mesleki Özerklik Sorunu Ve Süleyman Demirel Üniversitesi Sağllk Araştırma Ve Uygulama Merkezi'nde Ampirik Bir Çalışma. Ç.Ü.Sosyal Bilimler Enstitüsü Dergisi, 18(1), 133-148.

Dysvik, A., Kuvaas, B. (2011). Intrinsic Motivation As A Moderator On The Relationship Between Perceived Job Autonomy And Work Performance. European Journal of Work and Organizational Psychology, 20, 367- 387.

Engin, E. (2015). İşgörenlerin Örgütsel Destek Algılamalarının İş Tatmini Ve Örgütsel Bağlılık Üzerine Etkileri: Sanayi Ve Hizmet Sektörlerine Yönelik Bir Alan Araştırması. (Yayımlanmamış Doktora Tezi). Trakya Üniversitesi/Sosyal Bilimler Enstitüsü, Edirne.

Genç, E. (2018). Kamu Çalışanlarında Algılanan Örgütsel Desteğin İş Performansına Etkisinde Örgütsel Sinizmin Aracılık Rolü, Cumhuriyet Üniversitesi İktisadi ve İdari Bilimler Dergisi, 19 (2), 169-183. 
Gürbüz, S. ve Şahin, F. (2014). Sosyal Bilimlerde Araştırma Yöntemleri. Ankara: Seçkin Yayınevi.

Hayes, A. F. (2013). An Introduction to Mediation, Moderation, and Conditional Process Analysis: A Regression-Based Approach. New York, NY: Guilford Yayınları.

Ilyash, O., Yıldırım, O., Capuk, S., Bozgül, N. (2019). The Impact of Work Autonomy and Organizational Commitment on Organizational Communication. Journal of Behavior Studies in Organizations, 2, 10-17.

İçerli, L. ve Yıldırım, M. H. (2012). Örgütsel Sinisizm Ve Örgütsel Vatandaşlık Davranışı Arasındaki İlişki: Sağlik Sektöründe Bir Araştırma. Organizasyon ve Yönetim Bilimleri Dergisi, 4(1), 167-176.

Jones, M. D. (2006). Which is a Better Predictor of Job Performance: Job Satisfactionor Life Satisfaction?, Journal of Behavioral and Applied Management, 8 (1), 20-42

Kahya, C. (2013). Örgütsel Sinizm, İş Performansını Etkiler mi? İş Tatmininin Aracılık Etkisi, Global Journal of Economics and Business Studies, 2 (3), 34-46.

Kalağan, G. (2009). Araştırma Görevlilerinin Örgütsel Destek Algıları İle Örgütsel Sinizm Tutumları Arasındaki İlişki. (YayımlanmamışYüksek Lisans Tezi). Akdeniz Üniversitesi/Sosyal Bilimler Enstitüsü, Antalya.

Kale, E. (2015). Lider Desteği ve İş Arkadaşları Desteğinin İş Performansı Üzerine Etkileri: İş Tatmini ve Yaşam Tatmininin Aracı Rolü, International Journal of Economic and Administrative Studies, 7(14), 103-120.

Kasalak, G. (2019). The Relations Between Student Cynicism And Students' Life Satisfaction, International Journal of Contemporary Educational Research, 6(2), 325-337.

Kerse, G. ve Karabey, C. N. (2019). Örgütsel Sinizm ve Özdeşleşme Bağlamında Algılanan Örgütsel Desteğin İse Bağlanma ve Politik Davranış Algısına Etkisi, Eskişehir Osmangazi Üniversitesi İ̈BF Dergisi, 14 (1), 83-108.

Kılınç, E., Paksoy, M. (2017). Sağlık Çalışanlarında Performans Algı Düzeyinin Bazı Sosyo-Demografik Değişkenlere Göre İncelenmesi, Selçuk Üniversitesi Sosyal Bilimler Meslek Yüksekokulu Dergisi, 20 (2), 151-159.

Khan, A., H., Nawaz, M., M., Aleem, M., Hamed, W. (2012). Impact Of Job Satisfaction On Employee Performance: An Empirical Study Of Autonomous Medical Institutions Of Pakistan. African Journal of Business Management, 6 (7), 2697-2705.

Köroğlu, P., Yardan, E. D. (2016). Sağlık Kurumu Çalışanlarının Örgütsel Adalet Algılarının Örgütsel Sinizm Tutumlarına Etkisi, Akademik Sosyal Araştırmalar Dergisi, 4 (31), 11-34.

Kuvaas, B., Buch, R., Dysvik, A. (2016). Performance Management: Perceiving Goals as Invariable and Implications for Perceived Job Autonomy and Work Performance, Human Resource Management, 55 (3), 401-412.

Kwantesa, C. T., Bond, M. H. (2019). Organizational Justice And Autonomy As Moderators Of The Relationship Between Social And Organizational Cynicism. Personality and Individual Differences, 151, 1-10.

Kutaniş, P. (2018). Kendi Kendine Liderlik Tarzının İş Tamini ve İş Özerkliği Üzerindeki Etkisini Belirlemeye Yönelik Bir Araştırma. (Yayımlanmamış Yüksek Lisans Tezi), Hacettepe Üniversitesi/ Sosyal Bilimler Enstitüsü, Ankara.

Lin, J. T. P., Ping, N. C. L. (2016). Perceived Job Autonomy and Employee Engagement as Predictors of O r g a $\mathrm{n}$ i z a ti o $\mathrm{n}$ a 1 Co $\mathrm{m} \mathrm{m}$ it $\mathrm{m}$ e $\mathrm{n} \mathrm{t}$, Undergraduate Journal of Psychology. 29 (1), 1-16

Mehdinezhad, V. (2015). Students' satısfaction With Life And Its Relation To School Burnout. Bulgarian Journal of Science and Education Policy (BJSEP), 9(2), 254-265.

Meydan, C. H., Şen, H. (2011). Yapısal Eşitlik Modellemesi AMOS Uygulamaları. Ankara: Detay Yayıncılık. 
Naqvi, S. R., Ishtiaq, M., Kanwal, N., Ali, M. (2013). Impact of Job Autonomy on Organizational Commitment and Job Satisfaction: The Moderating Role of Organizational Culture in Fast Food Sector of Pakistan. International Journal of Business and Management, 8(17), 92-102.

Naus, F., Iterson, A., Roe, R. A. (2007). Value İncongruence, Job Autonomy, And Organization-Based SelfEsteem: A Self-Based Perspective On Organizational Cynicism, European Journal of Work and Organizational Psychology, 16 (2), 195-219.

Nylenna, M., Gulbrandsen, P., Førde, R., Aasland, O. G. (2005). Unhappy Doctors? A Longitudinal Study Of Life And Job Satisfaction Among Norwegian Doctors 1994- 2002. BMC Health Services Research, 5 (44), $1-6$.

Özdevecioğlu, M., Aktaş, A. (2007). Kariyer Bağl1lığı, Mesleki Bağlllık ve Örgütsel Bağl1lığın Yaşam Tatmini Üzerindeki Etkisi: İş-Aile Çatışmasının Rolü, Erciyes Üniversitesi İktisadi ve İdari Bilimler Fakültesi Dergisi, 28, 1- 20.

Özkara, Z. U., Taş, A. ve Aydıntan, B. (2019). Algılanan Yönetici Desteği İle Örgütsel Sinizm Arasındaki İlişkide Lider-Üye Etkileşiminin Aracılık Etkisi. OPUS-Uluslararası Toplum Araştırmaları Dergisi, 12(18. UiKK Özel Sayısı), 101-137.

Özkoç, A. G. (2016). Job Autonomy and Work Alienation: Organizational and Occupational Identification as a Mediator. European Journal of Business and Management, 8(11), 61-73.

Özyer, K. Irk, E. Ve Anaç, S. (2015). İş Tatmini Ve Yaşam Tatmini İlişkisinde İş Arkadaşlığının Aracılık Rolü, C.Ü. İktisadi ve İdari Bilimler Dergisi, 16 (1), 261-278.

Özyılmaz, F. Z. (2018). Duygusal Zekâ, Yaşam Tatmini Ve İş Performansı Arasındaki İlişkilerin İncelenmesi: Ağrı İbrahim Çeçen Üniversitesinde Ve Bayburt Üniversitesinde Çalışan Akademisyenler Üzerinde Bir Uygulama. (Yayımlanmamış yüksek lisans tezi). Ağrı İbrahim Çeçen Üniversitesi/Sosyal Bilimler Enstitüsü, Ağr1.

Pekdemir, I, Koçoğlu, M., Gürkan, G. Ç. (2014). Özerklik ve Ödüllendirme Algılarının Çalışan Performansı Üzerindeki Etkisinde Çalışanın Inovasyona Yönelik Davranışının Aracılık Rolüne Yönelik Bir Araştırma. İstanbul Üniversitesi İşletme Fakültesi Dergisi, 43(2), 332-350.

Pekel, A., Karaoğlu, B., Atar, Ö. (2016). Üniversite Yöneticilerinin Yaşam Tatmini İle Çalışma Performanslarının Bazi Değişkenlere Göre İncelenmesi (Erciyes Üniversitesi Örneği), Akademik Sosyal Araştırmalar Dergisi, 4(29), 384-393.

Ranaweera, C., Dharmasiri, A. S. (2016). Generation Y and Their Job Performance, Sri Lankan Journal of Management, 21 (1), 39-83.

Rode, J., Arthaud-Day, M., Mooney, C., Near, J., Baldwin, T. T., Bommer, W., Rubin R. (2005). Life Satisfaction And Student Performance. Academy of Management Learning and Education, 4 (4), 421-433.

Rhoades, L., ve Eisenberger, R. 2002. Perceived Organizational Support: A Review Of The Literature. Journal of Applied Psychology, 87 (4), 698-714.

Saragih, S. (2011). The Effects of Job Autonomy on Work Outcomes: Self Efficacy as an Intervening Variable, International Research Journal of Business Studies, 4 (3), 203-215.

Shaharruddin, S., Ahmad, F. B. (2016). Fighting Synicism in Organizations: The Role of Job Autonomy. Journal for Studies in Management and Planning (JSMaP), 2(8), 1-17.

Shaharruddin, S., Ahmad, F. B. (2015). The Influence of Job Autonomy on Organizational Cynicism: The Reliability Test. International Journal of Research in Business Studies and Management, 2(11), 91-100.

Shahzad, M. B. (2016). Impact Of Perceived Job Autonomy On Turnover Intention In Sales \& Marketing Managers Of Services Industry: Moderating Role Of Procedural And Distributive Justice. Sci Int, 28(3), 2881-2896.

Sonnentag, S., Volmer, J., Spychala, A. (2008). Job performance, in Barling, J. and Cooper C.L. (Eds), The SAGE Handbook of Organizational Behavior, Vol. 1: Micro Approaches, Sage Publications, London, 427-447. 
Şantaş, F., Uğurluoğlu, Ö., Kandemir, A., Çelik, Y. (2016). Sağlık Çalışanlarında Örgütsel Sinizm, İş Performansı Ve Örgütsel Özdeşleşme Düzeyleri Arasındaki İlişkilerin İncelenmesi. Gazi Üniversitesi İktisadi ve İdari Bilimler Fakültesi Dergisi, 18(3), 867-886.

Taştan, S., İşçi, E., Arslan B. (2014). Örgütsel Destek Algısının İşe Yabancılaşma ve Örgütsel Bağlllığa Etkisinin İncelenmesi: İstanbul Özel Hastanelerinde Bir Çalışma. Pamukkale Üniversitesi Sosyal Bilimler Enstitüsü Dergisi, 19, 121-138.

Tekingündüz, S , Top, M., Seçkin, M. (2015). İş Tatmini, Performans, İş Stresi Ve İşten Ayrilma Niyeti Arasindaki İlişkilerin İncelenmesi: Hastane Örneği, Verimlilik Dergisi, 0 (4), 39-64 .

Tokgöz, N., Yılmaz, H. (2008), Örgütsel Sinisizm: Eskişehir ve Alanya' daki Otel İşletmelerinde Bir Uygulama, Anadolu Üniversitesi Sosyal Bilimler Dergisi, 8 (2), 238-305.

Tokgöz, N. (2011). Örgütsel Sinisizm, Örgütsel Destek ve Örgütsel Adalet İlişkisi: Elektrik Dağıtım İşletmesi Çalışanları Örneği, Eskişehir Osmangazi Üniversitesi İ̈BFDergisi, 6(2), 363-387.

Torun, Y., Çetin, C. (2015). Örgütsel Sinizmin Kuşaklar Bazında Değerlendirilmesi: Kuşaklara Göre Örgütsel Sinizmin Hedefinde Ne Var?, İş ve İnsan Dergisi, 2(2), 137-146.

Tunç, B. (2018). Sağlık Kurumlarında Örgütsel Vatandaşlık Davranışı, İş Özerkliği, Örgüt Güvenlik İklimi, Duygusal Zeka, Sinizm Ve Tükenmişlik Arasındaki İlişkiler ve Bir Araştırma, (Yayımlanmamış yüksek lisans tezi), İstanbul Arel Üniversitesi/Sosyal Bilimler Enstitüsü, İstanbul.

Turunç, Ö., Çelik, M. (2010). Algılanan Örgütsel Desteğin Çalışanların İşAile, Aile-İş Çatışması, Örgütsel Özdeşleşme ve İşten Ayrılma Niyetine Etkisi: Savunma Sektöründe Bir Araştırma. Atatürk Üniversitesi Sosyal Bilimler Enstitüsü Dergisi, 14 (1). 209-232.

Tutar, H., Köse, S. (2018). Örgütsel Adaletsizlik Ve Sessizlik İlişkisindeörgütsel Sinizmin Düzenleyici Rolü, International Journal Entrepreneurship and Management Inquiries (Journal EMI) Dergisi, 2 (3), 152175 .

Uludağ, G. (2019). Yaşam Doyumu İle İşgören Performansı İlişkisini İncelemeye Yönelik Bir Alan Araştırması, Anemon Muş Alparslan Üniversitesi Sosyal Bilimler Dergisi, 7(6) 291-300.

Uğur, D. (2017). Psikolojik Sermaye ve Örgütsel Adaletin İş Performansı Üzerindeki Etkisi. (Yayımlanmamış yüksek lisans tezi). Yıldız Teknik Üniversitesi/Sosyal Bilimler Enstitüsü, İstanbul.

Uysal, H. T., Yıldız, M. S. (2014). İşgören Performansı Açısından Çalışma Psikolojisinin Örgütsel Sinizme Etkisi, The Journal of International Social Research, 7 (29), 835-849.

Yavuz, A. ve Bedük, A. (2016). Örgütsel Sinizm ve Örgütsel Bağlllık Arasındaki İlişki: Bir Kamu Bankasının Konya Şubelerinde Örnek Uygulam, Selçuk Üniversitesi Sosyal Bilimler Enstitüsü Dergisi, 35, 301-313.

Yelboğa, A. (2006). Kişilik Özellikleri ve İş Performansı Arasındaki İlişkinin İncelenmesi, İş Güç Endüstri İlişkileri ve İnsan Kaynaklarn Dergisi, 8 (2), 196-211.

Yen-Ju Lin, B., Ka1-Lin, Y., Chien-Lin, C. ve Tse-Lin, T. (2011). Job Autonomy, İts Predispositions And İts Relation To Work Outcomes İn Community Health Centers İn Taiwan, Health Promotion International, 28 (2), 166-177.

Yıldırım, A., Demirel, E. T. (2015). Ücret Tatmininin Yaşam Tatminini Belirleyici Etkisi Var Mı? Elazı̆̆ Banka Çalışanları Örneği, Fırat Üniversitesi Sosyal Bilimler Dergisi, 25 (2), 133-154.

Yıldırım, M., Acar, A. (2018). Influence Of The Work-Family Conflict On Organizational Cynicism and Intermediary Role of The Life Satisfaction, Journal of Yaşar University, 13 (51), 267-280.

Yıldırım, E., Akın, M. (2018). Örgütlerde Dışlanma, Sinizm ve Pozitif-Negatif Duygusallık Arasındaki İlişkiler: Pozitif Ve Negatif Duygusallığın Aracılık Rolü, Uluslararası Yönetim İktisat ve İşletme Dergisi, 14 (2), 427-449. 